\title{
Holocene climate variations in the western Antarctic Peninsula: evidence for sea ice extent predominantly controlled by changes in insolation and ENSO variability
}

\author{
J. Etourneau ${ }^{1}$, L. G. Collins ${ }^{1}$, V. Willmott ${ }^{2}$, J.-H. Kim ${ }^{2}$, L. Barbara ${ }^{3}$, A. Leventer ${ }^{4}$, S. Schouten ${ }^{2}$, J. S. Sinninghe \\ Damsté $^{2}$, A. Bianchini ${ }^{4}$, V. Klein ${ }^{1}$, X. Crosta ${ }^{3}$, and G. Massé ${ }^{1}$ \\ ${ }^{1}$ LOCEAN, UMR7159, CNRS/UPMC/IRD/MNHN, 4 Place Jussieu, 75252 Paris, France \\ ${ }^{2}$ Royal Netherlands Institute for Sea Research, Department of Marine Biogeochemistry and Toxicology, \\ 1790 Den Burg, Texel, the Netherlands \\ ${ }^{3}$ EPOC, UMR5805, CNRS - Université Bordeaux 1, Avenue des Facultés, 33405 Talence, France \\ ${ }^{4}$ Colgate University, Department of Geology, 13 Oak Drive, 13346 Hamilton, USA \\ Correspondence to: J. Etourneau (johan.etourneau @locean-ipsl.upmc.fr)
}

Received: 6 December 2012 - Published in Clim. Past Discuss.: 2 January 2013

Revised: 30 May 2013 - Accepted: 2 June 2013 - Published: 5 July 2013

\begin{abstract}
The West Antarctic ice sheet is particularly sensitive to global warming and its evolution and impact on global climate over the next few decades remains difficult to predict. In this context, investigating past sea ice conditions around Antarctica is of primary importance. Here, we document changes in sea ice presence, upper water column temperatures $(0-200 \mathrm{~m})$ and primary productivity over the last $9000 \mathrm{yr}$ BP (before present) in the western Antarctic Peninsula (WAP) margin from a sedimentary core collected in the Palmer Deep Basin. Employing a multi-proxy approach, based on the combination of two biomarkers proxies (highly branched isoprenoid (HBI) alkenes for sea ice and $\mathrm{TEX}_{86}^{\mathrm{L}}$ for temperature) and micropaleontological data (diatom assemblages), we derived new Holocene records of sea ice conditions and upper water column temperatures. The early Holocene (9000-7000 yr BP) was characterized by a cooling phase with a short sea ice season. During the midHolocene ( 7000-3800 yr BP), local climate evolved towards slightly colder conditions and a prominent extension of the sea ice season occurred, promoting a favorable environment for intensive diatom growth. The late Holocene (the last $\sim 2100 \mathrm{yr}$ ) was characterized by warmer temperatures and increased sea ice presence, accompanied by reduced local primary productivity, likely in response to a shorter growing season compared to the early or mid-Holocene. The gradual increase in annual sea ice duration over the last $7000 \mathrm{yr}$
\end{abstract}

might have been influenced by decreasing mean annual and spring insolation, despite increasing summer insolation. We postulate that, in addition to precessional changes in insolation, seasonal variability, via changes in the strength of the circumpolar Westerlies and upwelling activity, was further amplified by the increasing frequency/amplitude of the El Niño-Southern Oscillation (ENSO). However, between 3800 and $2100 \mathrm{yr} \mathrm{BP}$, the lack of correlation between ENSO and climate variability in the WAP suggests that other climatic factors might have been more important in controlling WAP climate at this time.

\section{Introduction}

The Antarctic seasonal sea ice cycle impacts oceanatmosphere heat and gas fluxes (Anderson et al., 2009), the formation of deep and intermediate waters that participate in driving the thermohaline circulation (e.g., Orsi et al., 2002), biogeochemical cycles and local biological production (Marinov et al., 2006; Sarmiento et al., 2004; Toggweiler et al., 2006). The Antarctic seasonal sea ice cycle has been strongly affected by recent warming, especially in the western Antarctic sector where the seasonal duration of sea ice has decreased by over $85 \pm 20$ days between 1979 and 2004 (Stammerjohn et al., 2008a). In the WAP, global warming 
has had a stronger and faster effect than in any other region of Antarctica (Vaughan et al., 2003; Steig et al., 2009), with a pronounced acceleration over the last few decades (Abram et al., 2013). For instance, the WAP has experienced a winter air warming trend of almost $\sim 3^{\circ} \mathrm{C}$ since the 1950's (e.g., Vaughan et al., 2003), which has been associated with the increasingly reduced duration of winter sea ice cover (Stammerjohn et al., 2008a), and the widespread retreat of WAP ice shelves (Doake and Vaughan, 1991; Rott et al., 1996; Vaughan and Doake, 1996). Subsurface ocean warming of $+0.3^{\circ} \mathrm{C}$ (the 0-300 $\mathrm{m}$ upper layer) over the last century (Levitus et al., 2000) strongly affects ice shelf stability in some sectors of West Antarctica and has the potential to significantly increase global sea level (King, 1994; Joughin and Alley, 2011; Rignot, 2006).

Bentley et al. (2009) provide a comprehensive review of Holocene paleoclimate records from the Antarctic Peninsula, including data from ice cores and lacustrine and marine sediment cores. Similarly, Taylor and Sjunneskog (2002) and Allen et al. (2010) summarized existing proxy data sets. These records, which show some regional variability in the timing and expression of the climate signal, document two warm periods, the first during the early Holocene and the second, during the "Mid-Holocene Hypsithermal" (Bentley et al., 2009). Recent marine geochemical data from the Palmer Deep (WAP), based on the TEX 86 proxy, similarly document a relatively warm early Holocene (Shevenell et al., 2011). Average sea surface temperatures (SST) of $3.7 \pm 2.2^{\circ} \mathrm{C}$ are evident between 11800 and $9000 \mathrm{yr}$ BP, with occasional peaks reaching $+10^{\circ} \mathrm{C}$, which are followed by millennialscale variations in SST, superimposed onto an overall cooling of $3-4{ }^{\circ} \mathrm{C}$ throughout the Holocene. This climatic trend is consistent with recent reconstructions of glacial ice fluctuations where an increasing discharge has been reported between 11500 and $9000 \mathrm{yr}$ BP, followed by a strong reduction and stabilization until $3600 \mathrm{yr} \mathrm{BP}$, prior to enhanced variability and a second period of strong melting during the late Holocene (Pike et al., 2013). A newly published ice core record from James Ross Island, Eastern Antarctic Peninsula (Mulvaney et al., 2012), also documents a warm early Holocene, with atmospheric temperatures approximately $+1.3 \pm 0.3{ }^{\circ} \mathrm{C}$ warmer than today. The ice core record revealed a relative cooling of $\sim 1{ }^{\circ} \mathrm{C}$ from $\sim 9200$ to $5000 \mathrm{yr} \mathrm{BP}$, slightly warmer temperatures from $\sim 5000$ to 3000 yr BP, corresponding to the "Mid-Holocene Hypsithermal", and a second gradual cooling of $\sim 1^{\circ} \mathrm{C}$ over the late Holocene.

Here, we provide a new multi-proxy record from a core located in the Palmer Deep Basin (WAP), on the continental open shelf, south of Anvers Island. We combine more traditional diatom assemblage data with more recent developments in multi-proxy analytical work, including a temperature record based on the well-calibrated $\mathrm{TEX}_{86}^{\mathrm{L}}$ paleothermometer, and a high-resolution record of specific diatom biomarker lipids, the highly branched isoprenoid (HBI)

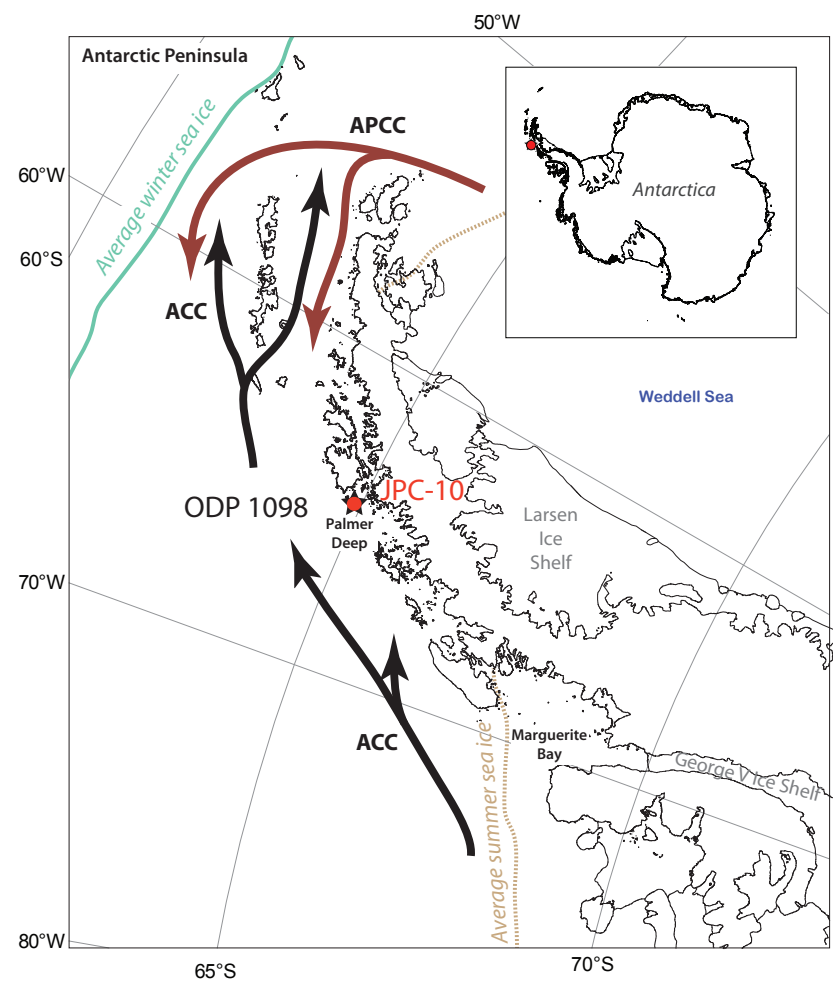

Fig. 1. Location of the JPC-10 core and the ODP Site 1098 in the Western Antarctic Peninsula (WAP). The dashed yellow line represents the limit of sea ice presence during the summer while the solid green line delineates the maximum sea ice extent during the winter. Major oceanic currents: ACC (Antarctic Circumpolar Current) and APCC (Antarctic Peninsula Circumpolar Counter-current), which is derived from the Weddell Sea surface waters.

alkenes, which are directly related to sea ice variability (Massé et al., 2011). Combining these records has enabled us to assess Holocene climatic changes in the central part of the WAP, and to compare our new data with other records from the region, including those from the nearby ODP Site 1098, also in the Palmer Deep (Domack et al., 2001; Leventer et al., 1996, 2002; Shevenell and Kennett, 2002; Sjunneskog and Taylor, 2002; Taylor and Sjunneskog, 2002; Ishman and Sperling, 2002; Shevenell et al., 2011), testing hypotheses presented previously to explain WAP climate fluctuations over the last $9000 \mathrm{yr}$ BP (insolation and ENSO) (e.g., Shevenell et al., 2011).

\section{Oceanographic setting}

The northern WAP is influenced by the Southern Ocean Westerlies and the Antarctic Circumpolar Current (ACC) (Fig. 1). The ACC mainly transports Circumpolar Deep Water (CDW) (Sievers and Nowlin, 1984), which is a relatively warm water mass and comprises an upper branch, the Upper Circumpolar Deep Water (UCDW), an oxygen minimum and high nutrient concentration layer, and a lower branch, 
the Lower Circumpolar Deep Water with a salinity maximum (Rintoul et al., 2001). CDW is derived from a mixture of deep waters arising from the North Atlantic, Pacific and Indian Oceans as well as waters formed in the Antarctic region. Due to Ekman pumping, CDW upwells onto the shelf when strong Westerlies are displaced south and penetrates the WAP shelf via deep glacial troughs (Klinck et al., 2004). In addition, strong offshore winds during the sea ice retreat season cause the relatively warm and salty UCDW $\left(1.5^{\circ} \mathrm{C}\right.$, 34.6-34.73 psu (Moffat et al., 2008)) to mix with Antarctic Surface Water (AASW). AASW forms in the upper 100$150 \mathrm{~m}$ of the water column and is mostly controlled by ice formation and melting, as well as wind forcing (Dierssen et al., 2002). AASW differs from UCDW by its cold temperatures and relatively low salinity (between -1.8 and $1{ }^{\circ} \mathrm{C}$, 33.0-33.7 psu) (Smith et al., 1999). During the ice-free season, the modified UCDW upwells heat and nutrients, which are important for biological productivity (e.g., Moffat et al., 2008). The vertical transport of relatively warm UCDW is believed to prevent high rates of sea ice production along the WAP shelf (Martinson et al., 2008).

Satellite monitoring demonstrates large spatial and temporal variability of sea ice along the WAP (Stammerjohn and Smith, 1996) and significant changes in sea ice duration over the past several decades (Stammerjohn et al., 2008a, b). While mean winter sea ice limits are located between 60 $63^{\circ} \mathrm{S}$, the average summer sea ice boundary lies between $67-69^{\circ} \mathrm{S}, 3-4^{\circ}$ south of Anvers Island (Fig. 1). There is little ice coverage during the austral summer, between January and April, with a minimum in March (Stammerjohn and Smith, 1996). Sea ice grows during the austral autumn and reaches its maximum cover in August (Stammerjohn and Smith, 1996), before melting between September and November. During the spring sea ice melt season, when temperatures warm, injections of fresh water, from the melting sea ice, stratify the water column, trap nutrients and phytoplankton in the light-rich photic zone and promote widespread primary production dominated by spring bloom diatom assemblages (Annett et al., 2010). Later in the summer season, brine-rich waters are mixed with deeper and warmer upwelled waters by the Westerlies and associated extratropical cyclonic flow, which renews the nutrient pool and promotes a second phytoplankton bloom (Moffat et al., 2008).

\section{Materials and methods}

We generated Holocene records by analyzing sediment slices of the Jumbo Piston NBP9903 Core 10 (JPC-10), collected during the United States Antarctic Program Cruise 03 in 1999 by the R/V Nathaniel B. Palmer. Core JPC-10, $13.33 \mathrm{~m}$ long and mainly composed of diatomaceous mud, was obtained from the Palmer Deep Basin $\left(64^{\circ} 53^{\prime} \mathrm{S}, 64^{\circ} 12^{\prime} \mathrm{W}\right.$, $905 \mathrm{~m}$ water depth), south of the Anvers Island, close to the ODP (Ocean Drilling Program) Site 1098 (64 $51^{\circ}$ S, $64^{\circ} 12^{\prime} \mathrm{W}, 1010 \mathrm{~m}$ water depth) (Fig. 1). Respectively, 326, 86 and 81 samples have been analyzed for HBI, TEX ${ }_{86}^{\mathrm{L}}$ and diatom census counts corresponding to a resolution of $\sim 25$, 100 and $110 \mathrm{yr}$ within age uncertainties. We additionally analyzed 19 sediment samples from the core drilled at the latter site (ODP 1098) for comparison with the record of Shevenell et al. (2011), derived from the same core. Sedimentary structures and physical properties of core JPC-10 are discussed in Domack et al. (2003) where they show that sediments are not disturbed by turbidites.

\subsection{Age model}

The age model for core JPC-10 was primarily based on the correlation of its magnetic susceptibility (MS) with the MS recorded at ODP Site 1098, which in turn has a robust agemodel derived from $54{ }^{14} \mathrm{C}$ dates (Domack et al., 2001). The two MS records show remarkably similar trends throughout the Holocene (Fig. 2). Correlation of the MS records of the two cores was further controlled by two carbonate shellsbased radiocarbon dates from core JPC-10. These two ${ }^{14} \mathrm{C}$ dates, at 1250 and $1323 \mathrm{~cm}$, were corrected using a 1230 year regional age reservoir (Domack et al., 2001) and calibrated using the Calib 6.1.1 radiocarbon calibration program, resulting in ages 8404 and $9040 \mathrm{yr}$ BP, respectively. The good correlation between JPC-10 and ODP 1098 sites allows for the reconstruction of Holocene variability at a centennial scale. According to the stratigraphy used, the top of core JPC-10 corresponds to $\sim 270 \mathrm{yr} \mathrm{BP}$ within the age model uncertainties. The sedimentation rate (SR) is $0.1-0.15 \mathrm{~cm} \mathrm{yr}^{-1}$ between 9000 and $8000 \mathrm{yr} \mathrm{BP}$ and again for the last $5000 \mathrm{yr}$ $\mathrm{BP}$, while during the intervening period, $8000-5000 \mathrm{yr} \mathrm{BP}$, the SR is higher, ranging between $0.2-0.3 \mathrm{~cm} \mathrm{yr}^{-1}$.

\subsection{Proxies}

\subsubsection{Biomarkers extraction}

For isoprenoid glycerol dibiphytanyl glycerol tetraethers (GDGTs) and highly branched isoprenoid (HBI) alkenes, lipids were first extracted at the Laboratoire d'Océanographie et du Climat: Experimentations et Approches Numériques (LOCEAN) using a mixture of $9 \mathrm{~mL}$ $\mathrm{CH}_{2} \mathrm{Cl}_{2} / \mathrm{MeOH}(2: 1, \mathrm{v}: \mathrm{v})$ to which internal standards (7 hexyl nonadecane, 9 octyl heptadecene and androstanol) were added. Several sonication and centrifugation steps were applied in order to properly extract the desired compounds. After drying with $\mathrm{N}_{2}$ at $35^{\circ} \mathrm{C}$, the total lipid extract was fractionated over a silica column into an apolar and a polar fraction using $3 \mathrm{~mL}$ hexane and $6 \mathrm{~mL} \mathrm{CH}_{2} \mathrm{Cl}_{2} / \mathrm{MeOH}(1: 1$, $\mathrm{v}: \mathrm{v})$, respectively. 


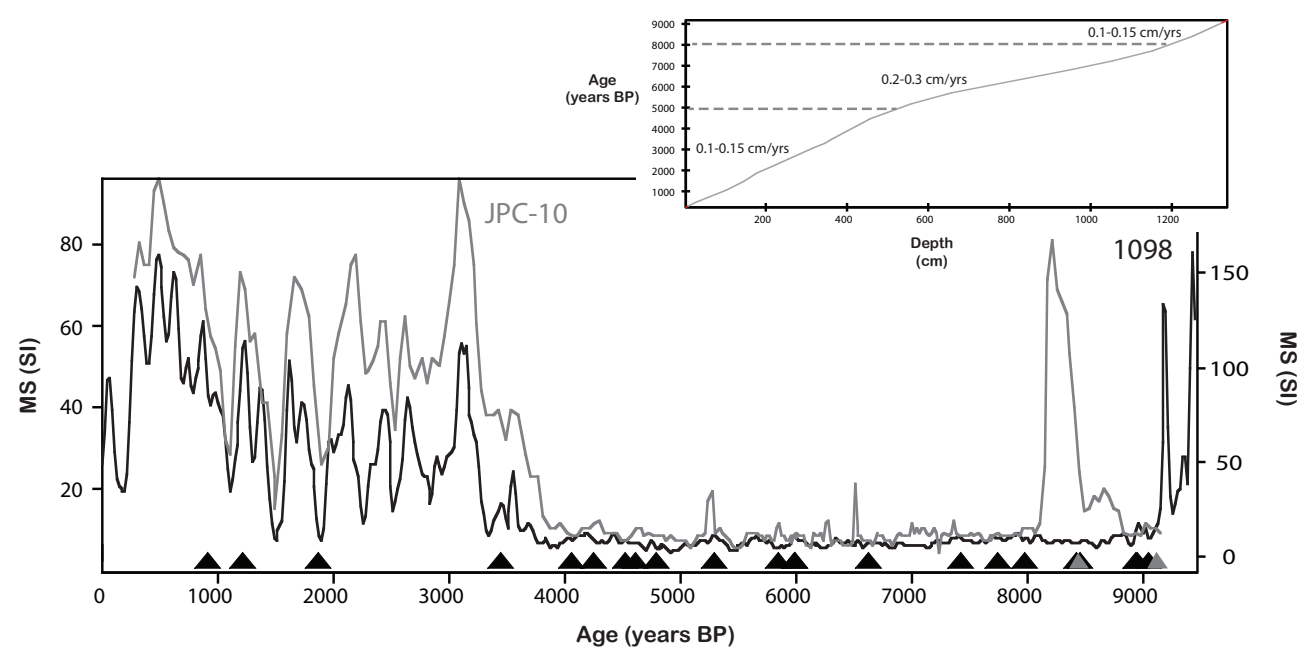

Fig. 2. Age model and sedimentation rate. The main panel represents the magnetic susceptibility (MS) correlation between the core JPC-10 and the ODP Site 1098. Grey and black markers indicate respective ${ }^{14} \mathrm{C}$ dates for core JPC-10 and Site 1098 . The upper, smaller panel shows the sedimentation of core JPC-10.

\subsubsection{TEX $\mathbf{T E}_{\mathbf{8 6}}^{\mathrm{L}}$}

The $\mathrm{TEX}_{86}$ (TetraEther Index of tetraethers with 86 carbon atoms) proxy is based on the relative distribution of Thaumarchaeotal lipids or GDGTs (Schouten et al., 2002). For temperature reconstruction, we measured $\mathrm{TEX}_{86}^{\mathrm{L}}$ at a centennial scale resolution. TEX $\mathrm{L}_{86}^{\mathrm{L}}$ is the modified form of $\mathrm{TEX}_{86}$ and is recommended for application in polar oceans (Kim et al., 2010). In contrast to a previous study in the WAP (Shevenell et al., 2011), which adapted the original TEX $_{86}$ proxy and performed a local calibration, we used $\mathrm{TEX}_{86}^{\mathrm{L}}$ as a proxy for reconstructing paleotemperature at the NBP9903 JPC-10 site. Correlation of the $\mathrm{TEX}_{86}$ index with SST $<10^{\circ} \mathrm{C}$, i.e., in the polar oceans, shows that changes in $\mathrm{TEX}_{86}$ are relatively minor with temperature and therefore this index is likely unsuitable for polar regions (Kim et al., 2008). Kim et al. (2010) readdressed the relationship of GDGTs with SST, leading to the definition of a new GDGT index, $\mathrm{TEX}_{86}^{\mathrm{L}}$, which minimizes the scatter at low temperatures and provides better absolute temperature estimates:

$\mathrm{TEX}_{86}^{\mathrm{L}}=\log \left(\frac{[\mathrm{GDGT}-2]}{[\mathrm{GDGT}-1]+[\mathrm{GDGT}-2]+[\mathrm{GDGT}-3]}\right)$

GDGT-1, GDGT-2, and GDGT-3 indicate GDGTs containing 1,2, and 3 cyclopentane moieties, respectively.

Since Thaumarchaeota are in low abundance in the Antarctic summer surface water (the $\sim 0-45$ m layer of low salinity water mass) but more abundant in winter and early spring in the $\sim 45-105 \mathrm{~m}$ depth interval of cold, salty water (i.e., the summer remnant of the previous winter, surfacemixed layer) (Kalanetra et al., 2009; Murray et al., 1998), we used the $\mathrm{TEX}_{86}^{\mathrm{L}}$ calibration established against the integrated
0-200 m water depth temperatures (see Kim et al., 2012):

$$
\begin{gathered}
T=50.8 \times \mathrm{TEX}_{86}^{\mathrm{L}}+36.1\left(r^{2}=0.87, n=396,\right. \\
\quad p<0.0001,0-200 \mathrm{~m})
\end{gathered}
$$

It is also worthwhile noting that Thaumarchaeota are found in Antarctic sea ice (Cowie et al., 2011), albeit in low abundance, and below the sea ice (Alonso-Sáez et al., 2012; Grzymski et al., 2012). This shows that their production may occur even below the freezing point of water (i.e., $<0^{\circ} \mathrm{C}$ ). The application of TEX ${ }_{86}^{\mathrm{L}}$ on core JPC-10 results in a $1.2^{\circ} \mathrm{C}$ temperature estimate for the most recent sediment (see results), which is within the range of the present annual mean temperature between 0-200 $\mathrm{m}$ at this location (Martinson et al., 2008). Thus, while there are still many remaining issues that should be resolved by further studies, this proxy seems to be appropriate for the reconstruction of temperature in sediment records from polar oceans with an associated residual standard error of $\pm 2.8^{\circ} \mathrm{C}$ (Kim et al., 2012). In order to depict a regional temperature pattern in the WAP, we also analyzed 19 samples from core ODP 1098 (Hole B), taken at the same depth intervals as Shevenell et al. (2011), who previously reported $\mathrm{TEX}_{86}$ temperature estimates.

Prior to analysis, the collected polar fraction containing the GDGTs was re-dissolved by sonication $(5 \mathrm{~min})$ in a $n$ hexane : 2-propanol (99:1,v:v) solvent mixture, and filtered through $0.45 \mu \mathrm{m}$ PTFE filters at the Royal Netherlands Institute for Sea Research (NIOZ). GDGT analyses were performed using an Agilent (Palo Alto, CA, USA) 1100 series LC-MS equipped with an auto-injector and Chemstation chromatography manager software (see Hopmans et al., 2000; Schouten et al., 2007). Separation was achieved on a Prevail Cyano column $(2.1 \times 150 \mathrm{~mm}, 3 \mathrm{~m}$; Alltech, Deerfield, IL 60015, USA), maintained at $30^{\circ} \mathrm{C}$, and an injection volume of $1 \mu$ l. GDGTs were eluted isocratically with $90 \% \mathrm{~A}$ 
and $10 \% \mathrm{~B}$ for $5 \mathrm{~min}$, followed by a linear gradient to $16 \% \mathrm{~B}$ in $45 \mathrm{~min}$, where $\mathrm{A}=$ hexane and $\mathrm{B}=$ hexane/propanol $(9: 1$, $\mathrm{v} / \mathrm{v})$. Flow rate was $0.2 \mathrm{~mL} \mathrm{~min}^{-1}$. After each analysis the column was cleaned by back-flushing hexane/propanol $(9: 1$, $\mathrm{v} / \mathrm{v}$ ) at $0.2 \mathrm{~mL} \mathrm{~min}^{-1}$ for $10 \mathrm{~min}$. Detection was achieved using atmospheric pressure positive ion chemical ionization mass spectrometry (APCI-MS). Conditions for the HP 1100 APCI-MS were as follows: nebulizer pressure $60 \mathrm{psi}$, vaporizer temperature $400^{\circ} \mathrm{C}$, drying gas $\left(\mathrm{N}_{2}\right)$ flow $6 \mathrm{~L} \mathrm{~min}^{-1}$ and temperature $200^{\circ} \mathrm{C}$, capillary voltage $-3 \mathrm{kV}$, corona $5 \mathrm{~A}$ $(\sim 3.2 \mathrm{kV})$. GDGTs were detected by selected ion monitoring $(\mathrm{SIM})$ of their $[\mathrm{M}+\mathrm{H}]^{+}$ions (dwell time $=234 \mathrm{~ms}$ ) (Schouten et al., 2007). Fractional abundances of each isoprenoid GDGT were obtained by normalizing each peak area to the summed area of all six isoprenoid GDGTs.

\subsubsection{Highly Branched Isoprenoids (HBIs)}

The concentrations of di and tri-unsaturated HBI lipids $\left(\mathrm{C}_{25: 2}\right.$ and $\mathrm{C}_{25: 3} \mathrm{HBI}$ alkenes, respectively), which are diatom-specific biomarkers (Volkman et al., 1994), were determined to reconstruct variations in past sea ice extent. It has been demonstrated that a di-unsaturated isomer (diene) is mainly synthesized by sea ice diatom species within the sea ice matrix during the warming spring months (Johns et al., 1999; Massé et al., 2011), whilst a tri-unsaturated HBI (triene) is produced by some open water diatom species (Belt et al., 2000; Massé et al., 2011). Contrary to the monoene IP25, a mono-unsaturated HBI isomer used in the Arctic Ocean for reconstructing past seasonal sea ice variability (Belt et al., 2007; Massé et al., 2008), recent and ongoing studies have highlighted the potential for the application of diene and triene concentrations and the resulting diene/triene $(\mathrm{D} / \mathrm{T})$ ratio as sea ice/open waters indicators in the Southern Ocean (Barbara et al., 2010; Denis et al., 2010; Massé et al., 2011). Given the absence of the monoene IP25 in the coastal areas surrounding Antarctica, determination of the concentrations and ratio of HBI alkenes, combined with diatom assemblage data, provides an important indication of the relative input of sea ice algae and open water phytoplankton to the sediment. This new proxy has recently been applied to the reconstruction of Antarctic paleoenvironments and used to successfully monitor the onset of deglaciation in Prydz Bay (Barbara et al., 2010), and the sea ice evolution through the Holocene in the Adélie Basin (Denis et al., 2010). Collins et al. (2013) have also recently evaluated the application of HBIs diene and triene to glacial age sediments from the deep ocean. While their interpretations differ somewhat to those presented here, we believe that this is due to the distinct disparate nature of the environmental settings featured in each respective study.

Compared to sea ice, glacial ice does not support an internal algal community and therefore is unlikely to directly influence the diene concentration. Regarding indirect influences, the calving of large icebergs has been shown to en- courage pack ice growth (Arrigo et al., 2002), which would affect the diene production and $\mathrm{D} / \mathrm{T}$ ratio. Although we consider the likely influence of glacial ice as minor, we cannot entirely exclude an indirect impact on diene concentrations during the Holocene. The HBI triene can be affected by broken ice shelves that may inhibit algal growth (especially the growth of Rhizosolenoid species, one of the main triene synthesizers; Belt et al., 2000) by shortening the growing season. This could be even more relevant under a warmer summer scenario, where upwelled warm UCDW waters would accelerate the ice shelf melting. It is also possible that a longer sea ice season, due to iceberg presence (Arrigo et al., 2002), could result in a more intense summer growth period due to greater sea ice melt-induced stratification in a high-light environment, thereby altering the triene concentration and the $\mathrm{D} / \mathrm{T}$ ratio.

Bacterial degradation is considered to have had minor effects on HBI sedimentary presence, given the good preservation of HBI over the last $60000 \mathrm{yr}$ (Collins et al., 2013) and their coherent evolution with diatom assemblages (Barbara et al., 2010; Denis et al., 2010; Collins et al., 2013). Furthermore, HBI structures appear to be relatively resistant to degradation (Robson and Rowland, 1988), although they may undergo rapid sulfurization under highly anoxic conditions (e.g., in the Antarctic Ellis Fjord; Sinninghe Damsté et al., 2007). While some sedimentary sulfur species were identified at certain depths in core JPC-10 sediments, GCMS analyses did not identify any organic sulfur compounds with an HBI carbon skeleton. We are therefore relatively confident that degradation is minimal throughout the core.

HBIs were obtained from the apolar fraction by fractionation over a silica column using hexane as eluent, following the procedures reported by Belt et al. (2007) and Massé et al. (2011). After removing the solvent with $\mathrm{N}_{2}$ at $35^{\circ} \mathrm{C}$, elemental sulfur was removed using the TBA (tetrabutylammonium) sulfite method (Jensen et al., 1977; Riis and Babel, 1999). The obtained hydrocarbon fraction was analyzed within an Agilent 7890A gas chromatograph (GC) fitted with $30 \mathrm{~m}$ fused silica Agilent J\&C GC column $(0.25 \mathrm{~mm}$ i.d., $0.25 \mu \mathrm{m}$ film thickness), coupled to an Agilent 5975C Series mass selective detector (MSD). The oven temperature in the GC was initially programmed at $40{ }^{\circ} \mathrm{C}$, then increased by $10^{\circ} \mathrm{C} \mathrm{m^{-1 }}{ }^{-1}$ up to $320^{\circ} \mathrm{C}$ where it was held for $12 \mathrm{~min}$. Spectra were then collected using the Agilent MS-Chemstation software. Individual HBIs were identified on the basis of comparison between their GC retention times and mass spectra with those of previously authenticated HBIs (e.g., Johns et al., 1999), and peaks of the two compounds were integrated using the Mass Hunter software. Values are expressed as concentration relative to the internal standards.

\subsubsection{Diatoms}

Diatom distribution and abundance in core JPC-10 was defined at a centennial scale resolution using the Crosta and 
Koç (2007) counting convention. Details regarding slide preparation and diatom identification are described in Crosta et al. (2004). Although the abundance of each diatom species was estimated as a percentage (\%) of the Chaetoceros-free diatom assemblage, the total diatom abundance, Chaetoceros resting spores (CRS) and non-CRS assemblage absolute abundance were expressed as $\mathrm{Mv} \mathrm{g}^{-1}$ (millions of valves per gram of sediment). Species recording less than $1 \%$ in every given sample were removed to decrease the effect of noise in the dataset, with the exception of several benthic species, which were grouped in a special benthic group. $E u$ campia specific counts, evaluating the relative abundances of the Eucampia antarctica var. recta ("polar" variety) versus Eucampia antarctica var. antarctica ("sub-polar" variety) and terminal versus intercalary valves, were completed by counting 100 specimens per slide if abundance permitted, or by counting all specimens on a slide.

Here, we selected a number of diatom indicator species and groups of indicator species that reflect specific environments. In the Antarctic Peninsula, diatom species distribution follows a well-marked latitudinal gradient. CRS mostly develop in the Antarctic Peninsula region and the embayment systems such as the Ross Sea and Weddell Sea (Crosta et al., 1997). Along the WAP, CRS are predominantly formed in the northern sector, which experiences a longer ice-free season (Buffen et al., 2007; Pike et al., 2008). Under these conditions algal blooms primarily occur during periods of most intense water column stratification, and exhaust surface nutrients (Crosta et al., 2007, 2008; Denis et al., 2006; Leventer et al., 1996). CRS are usually associated with high productivity events at the receding sea ice edge (Crosta et al., 2007, 2008; Denis et al., 2006; Leventer et al., 1996, 2002) and constitute most of the preserved diatom species found in the core JPC-10 sediments, accounting for more than $90 \%$ of the total diatom species. The dominance of CRS exerts a strong control on diatom absolute abundance. We therefore distinguished the total diatom abundance with and without CRS. We performed CRS-free counts in order to ensure that potentially important variations in the relative abundance of more minor diatom indicator species were not dampened by the overwhelming presence of CRS (e.g., Allen et al., 2005).

Other environmentally diagnostic and numerically abundant diatom species include the cold and warm varieties of Thalassiosira antarctica, which grow, respectively, at the sea ice edge when the duration of seasonal sea ice is greatest, and during the ice-free season (Buffen et al., 2007; Pike et al., 2009). Fragilariopsis curta, combined here with the very similar species Fragilariopsis cylindrus, is found close to sea ice (Buffen et al., 2007; Pike et al., 2008) and is used to reflect sea ice distribution. This ecological association has been widely applied by a number of authors (Crosta et al., 1998; Gersonde and Zielinski, 2000; Leventer, 1998; Gersonde et al., 2005; Allen et al., 2010; Collins et al., 2012). Currently, both $F$. curta and $F$. cylindrus are found to be more abundant in the southern WAP (Pike et al., 2008). Eucampia antarc- tica, also common in core JPC-10, has been documented to occur as two varieties, termed "sub-polar" and "polar", which are distinguished by valve symmetry (Fryxell, 1989; Fryxell and Prasad, 1990) and generally occur either north or south, respectively, of the Antarctic Convergence zone. In addition, a paleoenvironmental proxy based on the ratio of terminal to intercalary valves of $E$. antarctica has been used to record winter sea ice variability (Kaczmarska et al., 1993; Whitehead et al., 2005). The abundance of Fragilariopsis kerguelensis and Thalassiosira lentiginosa, which presently reside offshore and share a close relationship with the ACC, are used as indicators of open ocean conditions (Crosta et al., 2004), and might highlight summer sea surface temperatures (Crosta et al., 2007). Finally, the sea ice related diatom group is compared to the so-called benthic group (composed of Amphora, Cocconeis sp., Gomphonema, Licmophora and Navicula sp.), which include cryophilic diatoms that live in near-coastal sea ice, are commonly found during spring and summer blooms (Krebs, 1983).

\section{Results}

In core JPC-10, the Holocene $\mathrm{TEX}_{86}^{\mathrm{L}}$-derived temperature record (0-200 water depth) reached its maximum $\left(>+3{ }^{\circ} \mathrm{C}\right)$ at the bottom of the core, $\sim 9000 \mathrm{yr}$ BP (Fig. 3b). Following this peak, temperatures decreased to, and remained around, $+1.5^{\circ} \mathrm{C}$ until $\sim 7000 \mathrm{yr}$ BP. From $\sim 7000$ to $4200 \mathrm{yr} \mathrm{BP}$, temperatures declined from +1.6 to $+0.7^{\circ} \mathrm{C}$, prior to a brief period of warming between $\sim 4200$ and $3100 \mathrm{yr} \mathrm{BP}$ and a second cooling phase, which reached a low of $\sim+0.3{ }^{\circ} \mathrm{C}$ at $\sim 3100 \mathrm{yr}$ BP. Although the last $3100 \mathrm{yr}$ BP were characterized by variable temperatures with a mean of $+1.0^{\circ} \mathrm{C}$, the temperature record exhibited a peak at $\sim 1000 \mathrm{yr} \mathrm{BP}$, with values close to $+2.5^{\circ} \mathrm{C}$. In comparison, our $\mathrm{TEX}_{86}^{\mathrm{L}}$ record from ODP Site 1098 Hole B, covering the last $12000 \mathrm{yr}$ $\mathrm{BP}$, revealed a temperature range from $+3{ }^{\circ} \mathrm{C}$ to $+0.3{ }^{\circ} \mathrm{C}$ (Fig. 4a). Although the temporal resolution of our ODP Site 1098 record is relatively low, the general trends of both records (JPC-10 and ODP Site 1098) are in good agreement (Fig. $4 \mathrm{~b}$ ), both in terms of overall temperature range and in highlighting the abrupt decrease in temperature from $\sim 9000$ to $8200 \mathrm{yr} \mathrm{BP}$.

BIT values varied between 0.01 and 0.02 for both marine records (Fig. 4c). The low BIT values indicated that the input of soil organic matter (Hopmans et al., 2004) to our core sites was very low and, thus, did not influence our TEX $\mathrm{L}_{86}^{\mathrm{L}}$ record (Weijers et al., 2006). The present-day vertical temperature profile in the study area shows a surface mixed layer $(\sim 30 \mathrm{~m})$ with an average annual mean temperature of $-0.2^{\circ} \mathrm{C}$ and a 0-200 $\mathrm{m}$ water depth layer with an annual mean temperature of around $+0.3{ }^{\circ} \mathrm{C}$ (Levitus and Boyer, 1994). Hence, the estimated temperatures of the upper most sediments analyzed $\left(+1.2^{\circ} \mathrm{C}\right.$ for JPC- 10 and $+1.0^{\circ} \mathrm{C}$ for ODP1098) are well above the regional freezing point of seawater $\left(-1.7^{\circ} \mathrm{C}\right.$, 


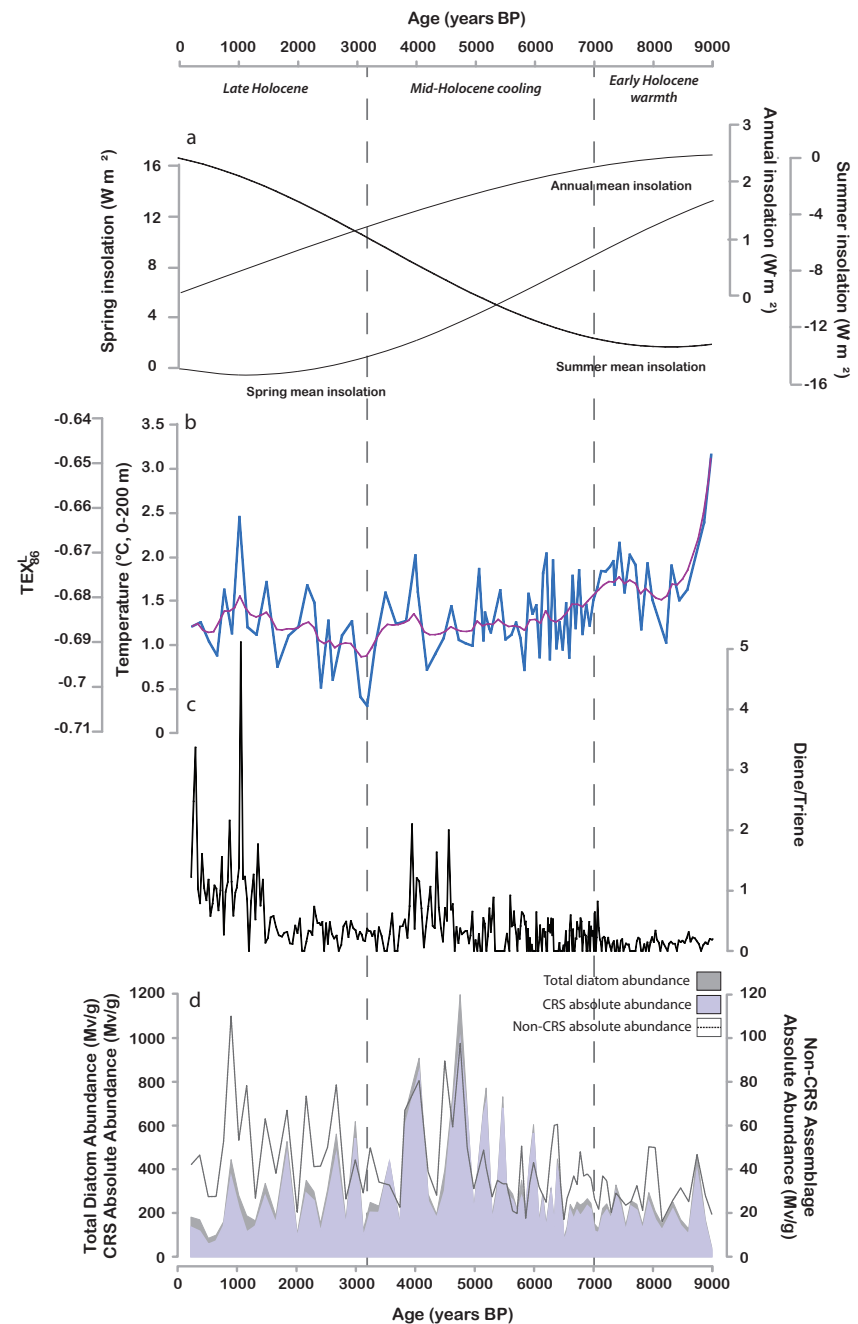

Fig. 3. Paleoclimatic proxies from core JPC-10 compared with Holocene insolation. (a) Annual, summer and spring mean insolation at $65^{\circ} \mathrm{S}$ (Berger and Loutre, 1991), (b) TEX ${ }_{86}^{\mathrm{L}}$ index and temperature $\left({ }^{\circ} \mathrm{C}, 0-200 \mathrm{~m}\right)$ record (blue) and the smoothed curve (red), (c) the $\mathrm{D} / \mathrm{T}$ ratio and (d) the total diatom abundance $\left(\mathrm{Mv} \mathrm{g}^{-1}\right)$, the CRS absolute abundance ( $\mathrm{Mvg}^{-1}$ ) and the non-CRS assemblage absolute abundance $\left(\mathrm{Mv} \mathrm{g}^{-1}\right)$. The two vertical solid dashed grey lines denote the early Holocene warmth, mid-Holocene cooling and late Holocene periods, following the reconstructed $\mathrm{TEX}_{86}^{\mathrm{L}}$ temperatures trend.

Martinson et al., 2008) and are only $+1.0^{\circ} \mathrm{C}$ warmer than the annual mean temperature of the $0-200 \mathrm{~m}$ water layer. Nevertheless, care has to be taken in interpreting the absolute values of $\mathrm{TEX}_{86}^{\mathrm{L}}$-derived reconstructions due to the relatively large calibration error $\left( \pm 2.8^{\circ} \mathrm{C}\right)$ (Fig. 4). Relative changes in $\mathrm{TEX}_{86}^{\mathrm{L}}$-derived temperature can be viewed with more confidence.

The HBI record (the ratio of $\mathrm{D} / \mathrm{T}$ ) is characterized by two intervals of relatively high values (Fig. 3c). Prior to $\sim 7000 \mathrm{yr}$ BP the ratio is uniformly low, close to 0 , before increasing to values of 1-2 throughout the period of mid-Holocene cool-
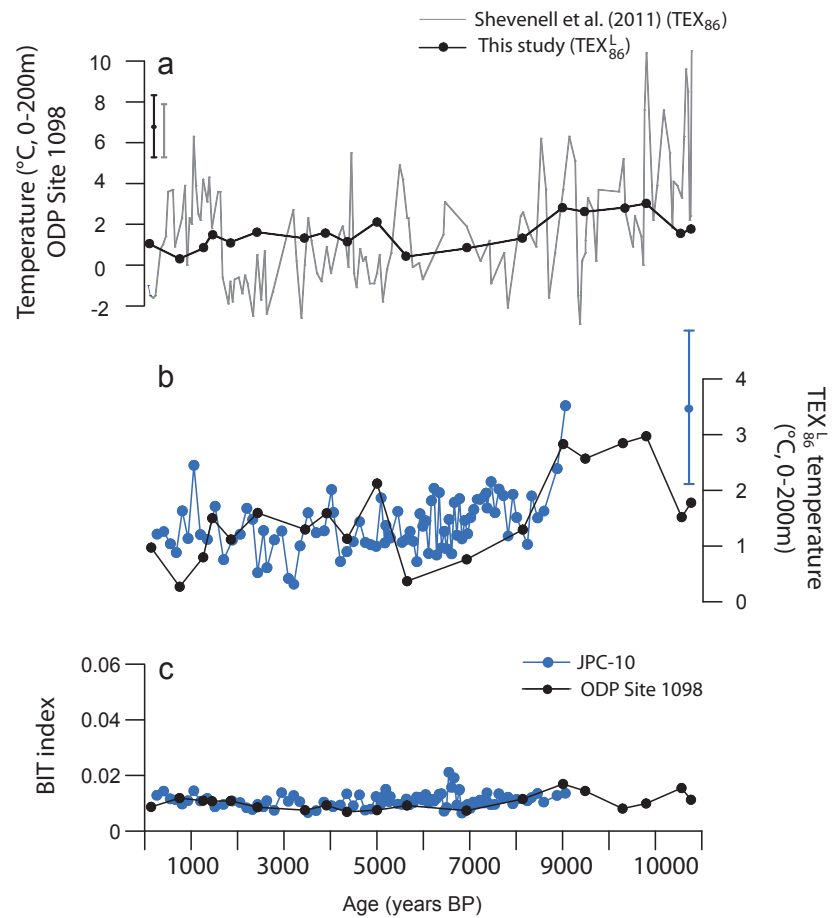

Fig. 4. (a) $\mathrm{TEX}_{86}^{\mathrm{L}}$ (this study) versus $\mathrm{TEX}_{86}$ (Shevenell et al., 2011) records at ODP Site 1098. (b) JPC-10 and ODP Site $1098 \mathrm{TEX}_{86}^{\mathrm{L}}$ records. Temperature total errors are indicated by vertical bars for each record with their respective colors. (c) JPC-10 and ODP Site 1098 BIT index records. Note the different temperature scale used between (a) and (b) due to the different temperature amplitude resulting from the application of two different indices and two different calibrations.

ing (Fig. 3c). The ratio showed lower and more stable values $(<1)$ prior to and during the late Holocene (3800 to $1500 \mathrm{yr}$ BP), before increasing again to higher values and a peak $>5$ around $1000 \mathrm{yr} \mathrm{BP}$, its highest values on average over the last $1200 \mathrm{yr}$ BP. The mid-Holocene cooling and late Holocene patterns resemble each other (increasing from low to high values), albeit with greater $\mathrm{D} / \mathrm{T}$ ratios during the late Holocene. Taken separately, diene concentration progressively increased from $7000 \mathrm{yr}$ BP to modern, with a sharp increase over the last $2100 \mathrm{yr}$ BP (Fig. 5), whereas triene concentration drastically decreased from 9000 to $3800 \mathrm{yr}$ BP before experiencing a period of gradual increase during the late Holocene, with peaks reached at 3000, 2000 and $500 \mathrm{yr}$ BP (Fig. 5).

The total diatom and CRS absolute abundance evolved similarly over the last $9000 \mathrm{yr}$ (Fig. 3). While the early Holocene warmth corresponded to low diatom and CRS abundance, around $200 \mathrm{Mvg}^{-1}$, the mid-Holocene cooling was characterized by the highest diatom abundance with two peaks of 1200 and $900 \mathrm{Mv} \mathrm{g}^{-1}$ at around 4800 and $3800 \mathrm{yr}$ BP, respectively. The late Holocene was marked by a decline in total diatom abundance with values close 


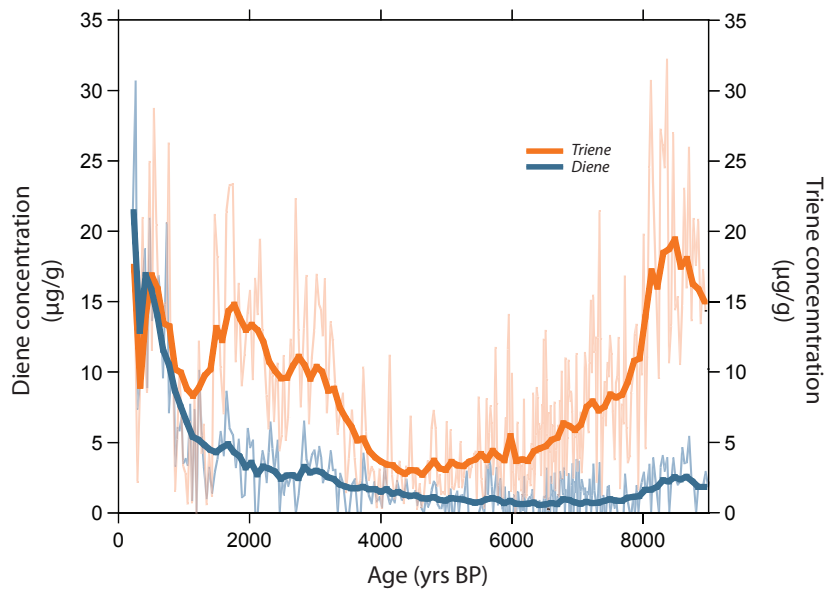

Fig. 5. Holocene diene (blue) and triene (orange) concentrations and their respective smoothed curves at the JPC-10 core site.

to those found prior to $7000 \mathrm{yr}$ BP. Absolute abundance of diatoms other than Chaetoceros (Non-CRS assemblage

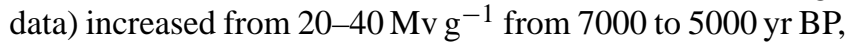
which is consistent with the total diatom abundance data, but then remained relatively high until the most recent part of the record (Figs. 3 and 6). CRS represent $80-90 \%$ of the total abundance during the early Holocene, and increased slightly to $90-95 \%$ during the mid-Holocene, prior to declining to $\sim 70 \%$ of the total abundance since $3800 \mathrm{yr}$ BP (Fig. 6).

The trend of $F$. curta and $F$. cylindrus showed a similar profile with low values, less than $10 \%$ of the non-CRS total abundance, before $7000 \mathrm{yr} \mathrm{BP}$, a net increase towards higher values during the mid-Holocene, reaching nearly $50 \%$ at $5500 \mathrm{yr} \mathrm{BP}$, followed by a decrease to values around 10 $20 \%$ over the last $1000 \mathrm{yr}$ (Fig. 6). In comparison, the cold variety of $T$. antarctica exhibited an overall increasing trend throughout the Holocene, rising from 2 to $12 \%$ (Fig. 6). The relative abundance of $T$. antarctica (cold) decreased slightly between 3800 and $2600 \mathrm{yr}$ BP prior to a strong increase over the last $2600 \mathrm{yr}$ BP (Fig. 6). The warm variety of $T$. antarctica depicts a different pattern, a progressive decrease from 25 to $5 \%$ between 9000 and $2600 \mathrm{yr}$ BP, interrupted by a period of higher values between 4500 and $2600 \mathrm{yr} \mathrm{BP}$, before a pronounced increase over the last $2600 \mathrm{yr}$ (Fig. 6).

E. antarctica represented a major component of the nonCRS total abundance between 9000 and $6000 \mathrm{yr}$ BP (20$40 \%$ ) with a dominance of the sub-polar variety of the species, but then declined sharply at $6000 \mathrm{yr}$ BP, representing a minor component throughout the remainder of the Holocene (mean 3.6\%). This decline was accompanied by the switch to a polar form of the species (Fig. 6). In addition, the ratio of terminal/intercalary $E$. antarctica valves was uniformly low until $6000 \mathrm{yr}$ BP and then became higher and more variable. $F$. kerguelensis and $T$. lentiginosa occurred in relatively high abundances (20-30\%) before $7000 \mathrm{yr}$ BP and progressively declined towards lower values thereafter, ranging between 10-20\%, over the course of the Holocene (Fig. 6). This trend is the reverse of the benthic group record, which revealed the lowest abundance during the early Holocene warmth, less than $3 \%$, before increasing to $>3 \%$ from $\sim 7000$ to $4000 \mathrm{yr} \mathrm{BP}$ and declining thereafter.

\section{Discussion}

\subsection{Local comparison of $\mathrm{TEX}_{86}^{\mathrm{L}}$ records in the WAP}

Our new TEX $\mathrm{L}_{86}^{\mathrm{L}}$-SST records from core JPC-10 and ODP Site 1098 Hole B (Fig. 4b) show a consistent picture of temperature variation in Palmer Deep Basin during the Holocene. However, our results give different temperature estimates in terms of amplitude and variations compared with

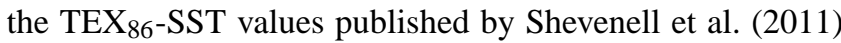
(Fig. 4a). These differences are firstly due to the different indices used (TEX ${ }_{86}^{\mathrm{L}}$ in our study and $\mathrm{TEX}_{86}$ in the study of Shevenell et al., 2011) as well as the different calibrations. We used the more extensive core-top data set of Kim et al. (2010) for our study, which contains far more data points from polar oceans than the calibration established by Kim et al. (2008) and used in Shevenell et al. (2011). Furthermore, we did not calibrate the $\mathrm{TEX}_{86}$ index against sea surface temperature but instead against the mean temperature integrated over the $0-200 \mathrm{~m}$ water depth range as outlined in Kim et al. (2012). Importantly, our ODP Site $1098 \mathrm{TEX}_{86}^{\mathrm{L}}$ record is fully consistent with that from core JPC-10 (Fig. 4b), suggesting that they represent a regional record of temperature variability.

\subsection{The Holocene climate in the WAP}

\subsubsection{The early Holocene}

Between $\sim 10000$ and $7000 \mathrm{yr} \mathrm{BP}, \mathrm{TEX}_{86}^{\mathrm{L}}$-derived temperatures were warmer than those during the mid- and late Holocene (Figs. 3 and 4). With the exception of a cooling event centered $\sim 8200 \mathrm{yr}$ BP - which might have been related to a global cooling phenomenon (Barber et al., 1999; Ellison et al., 2006; Morrill and Jacobsen, 2005; Rohling and Pälike, 2005) - temperatures varied from 1 to $3^{\circ} \mathrm{C}$, which is similar to modern observations under a warming climate (Martinson et al., 2008). Warm upper ocean temperatures are supported by the high relative abundance of $T$. antarctica (warm) (Fig. 7) and the uniformly low relative abundance of $T$. antarctica (cold) (Fig. 6). These relatively warm temperatures were likely accompanied by reduced seasonal sea ice presence, as illustrated by the very low $\mathrm{D} / \mathrm{T}$ ratio $(<0.3)$ (Fig. 3), the high (low) triene (diene) concentration (Fig. 5), the low relative abundances of diatoms groups associated with sea ice ( $F$. curta and $F$. cylindrus, the benthic diatom group), and the low ratio of terminal/intercalary $E$. antarctica valves. The prolonged open ocean conditions likely allowed for glacial melt and thus the production of 

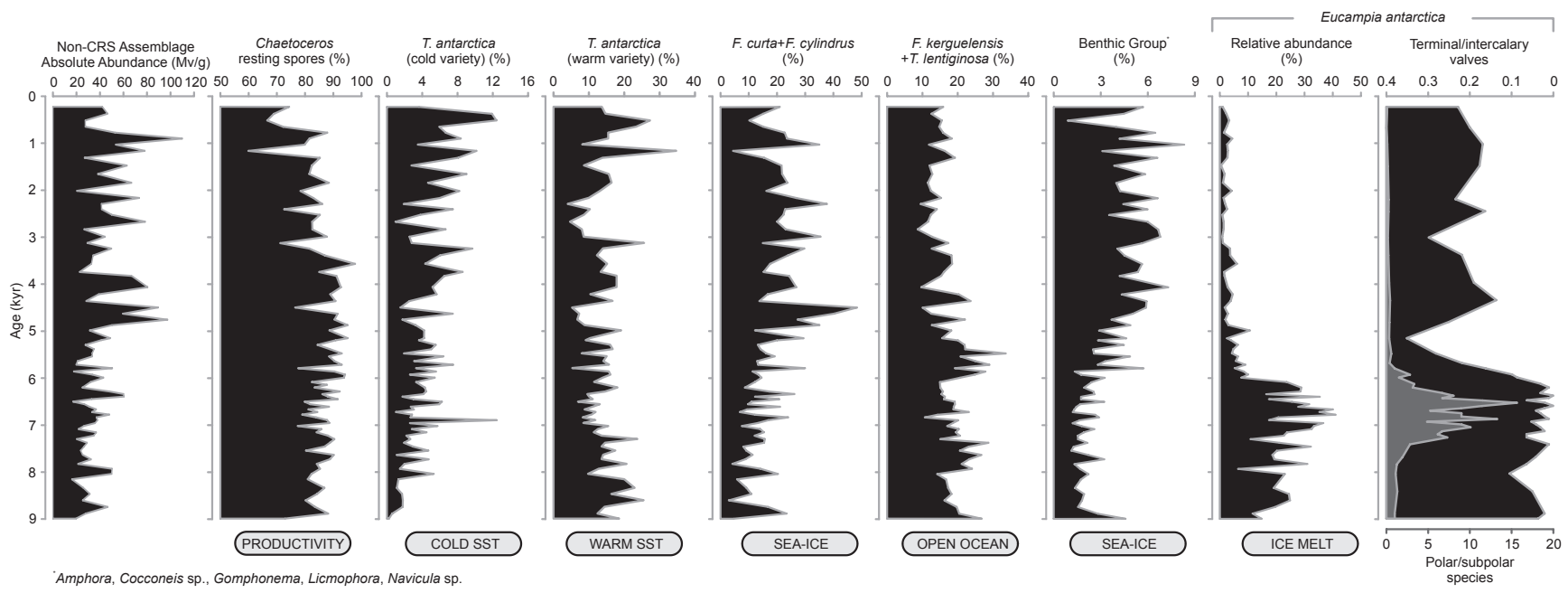

Fig. 6. Chaetoceros-free diatom relative abundance (\%) of selected environmental indicator species from core JPC-10. On the right panel, the grey curve indicates the ratio between polar and subpolar E. antarctica species, while the terminal and intercalary valves ratio is illustrated in black.

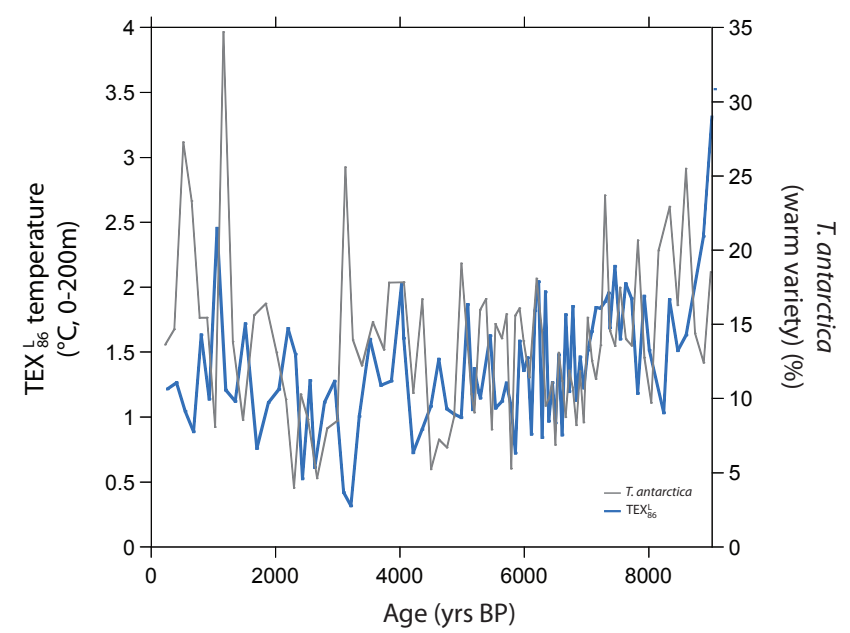

Fig. 7. Comparison between the JPC-10 $\mathrm{TEX}_{86}^{\mathrm{L}}$ temperature $\left({ }^{\circ} \mathrm{C}\right)$ and $T$. antarctica warm variety $(\%)$ records.

both stratification-related diatom species such as E. antarctica and CRS during spring and open ocean species such as F. kerguelensis and T. lentiginosa during summer (Fig. 6).

The early Holocene warm period $(\sim 12000-7000$ yr BP) has been recorded throughout the AP from both marine (Allen et al., 2010; Heroy et al., 2008; Pike et al., 2013; Sjunneskog and Taylor, 2002; Taylor et al., 2001; Taylor and Sjunneskog, 2002) and ice core records (Mulvaney et al., 2012), which report warmer conditions and/or weaker sea ice presence than today. High temperatures in our reconstructed record coincided with maximum annual and spring insolation since the onset of the Holocene (Fig. 3a). Warmerthan-modern winter and spring conditions would have limited sea ice persistence and prolonged the local sea ice-free season. Given the link between insolation and sea ice, we infer that the latter likely retreated early in the spring and advanced late in the autumn during the early Holocene warmth, as supported by diatom assemblages (Fig. 6). This would be consistent with warmer summer temperatures, estimated from model simulations to be slightly higher $\left(0.5^{\circ} \mathrm{C}\right)$ than today (Renssen et al., 2005), and by reconstructed atmospheric temperatures to be about $+1^{\circ} \mathrm{C}$ warmer than present (Mulvaney et al., 2012). Furthermore, such a scenario likely promoted the strong melting of glacial ice reconstructed at the same location during this time interval by Pike et al. (2013).

A longer and warmer summer season, alongside weaker sea ice presence, would have also likely favored the southward migration of the Westerlies, as previously hypothesized (Shevenell et al., 2011). The southward migration of the Westerlies might have in turn increased the upwelling of warm UCDW and its transport onto the shelf, thus leading to higher ocean temperatures between 1 and $2{ }^{\circ} \mathrm{C}$. In addition, increased wind-driven coastal upwelling along with the reduced amount of near-shore sea ice cover might have enhanced the transport of nutrient-rich waters to the surface and hence allowed the renewal of the nutrient pool in the euphotic zone. Long seasonal periods of stratified conditions, followed by strong upwelling activity, probably contributed in concert to stimulate diatom blooms during the early Holocene warmth along the WAP, as recorded, for instance, here in the Palmer Deep Basin.

\subsubsection{The mid-Holocene}

From $\sim 7000$ to $3800 \mathrm{yr} \mathrm{BP}$, increased $\mathrm{D} / \mathrm{T}$ ratio and diene concentration evolved in line with a drastic decline in triene concentration (Figs. 3c, 5), suggesting an increasing seasonal presence of spring sea ice. This is supported by the increasing 
abundance of diatom species diagnostic of sea ice presence (F. curta and F. cylindrus, E. antarctica and the benthic diatom group) (Fig. 6). Reduced open ocean conditions are supported further by the decreasing abundance of open ocean diatom indicators, $F$. kerguelensis and T. lentiginosa. It is likely that decreasing insolation during the winter and spring resulted in the development of a longer sea ice season during the mid-Holocene, which restricted the duration of the summer season, despite increasing summer insolation. This interpretation is supported by modeled temperatures that indicate a relatively continuous cooling of annual and spring temperatures of 1 and $2{ }^{\circ} \mathrm{C}$, respectively, over West Antarctica between $\sim 9000 \mathrm{yr}$ BP and today (Renssen et al., 2005). This cooling trend likely explains the concomitant slowdown and stabilization of glacial discharge in the same area (Pike et al., 2013). This interpretation is also consistent with our reconstructed $\mathrm{TEX}_{86}^{\mathrm{L}}$-derived temperature record and reconstructed atmospheric temperatures (Mulvaney et al., 2012) that show a similar profile during this time interval. The transition to a colder upper water column was also reflected in the overall decline (increase) in the relative abundance of the warm (cold) variety of $T$. antarctica at this time.

During the mid-Holocene period, the reconstructed environmental conditions along the AP do not show any clear homogenous picture of a regional climatic pattern (Allen et al., 2010; Domack et al., 2001; Heroy et al., 2008; Ishman and Sperling, 2002; Pike et al., 2013; Taylor and Sjunneskog, 2002; Taylor et al., 2001; Yoon et al., 2002). However, according to our results, sea ice probably retreated later in the spring and advanced earlier in the autumn than during previous Holocene periods. The melting of extensive sea ice would have led to stronger stratification of the water column, likely favoring the growth of Chaetoceros species and enhancing overall primary productivity in the Palmer Deep Basin, as also observed by Sjunneskog and Taylor (2002). In addition, a similar increase in marine primary productivity was reported in Lallemand Fjord (Taylor et al., 2001; Shevenell et al., 1996) and Marguerite Bay (Allen et al., 2010), although a decrease in CRS was reported for the former region. This could be related to the more southerly and coastal location of Lallemand Fjord, which may have contributed to stronger sea ice development that prevented the occurrence of large blooms of Chaetoceros.

The extension of Antarctic sea ice during the midHolocene (Nielsen et al., 2004; lizuka et al., 2008) might have displaced the Westerlies northward, and the resulting reduction in the upwelling of UCDW might have led to a diminished transport of warm water masses over the WAP shelf. However, Lamy et al. (2010) recently documented reduced precipitation in the $50-55^{\circ} \mathrm{S}$ latitudinal band, and thus inferred a southward migration and weakening of the Westerlies during this period. The role and positioning of the Westerlies throughout the Holocene has long been debated and remains controversial and unclear, with several studies pointing out conflicting results (e.g., Montade et al., 2012; Moreno et al., 2010). Comparison with our data would suggest a narrowing, instead of a poleward migration, of the westerly wind belt between the Antarctic Peninsula and southern Chile during the mid-Holocene. Due to the longer seasonal persistence of sea ice along the shore and the reduced effects of the katabatic and synoptic winds, decreased coastal upwelling would have acted to limit the intrusion of warm waters to the surface, thus further decreasing atmospheric temperatures, alongside declining annual and spring insolation, and would have therefore interrupted the melting of glacial ice (Pike et al., 2013).

\subsubsection{The late Holocene}

The concentrations of both diene and triene increased over the last $3800 \mathrm{yr}$, although with a greater variability evident in the latter (Fig. 5). The resulting D/T ratio subsequently demonstrates an abrupt shift at $\sim 2100 \mathrm{yr}$ BP, suggesting that the two last millennia corresponded to a period of increased sea ice presence (Fig. 3c). During this period, the D/T ratio and diene concentration records both suggest the greatest sea ice duration since the onset of the Holocene, which is consistent with previous findings further south (Allen et al., 2010) and north (Heroy et al., 2008). Increased sea ice presence is additionally supported by continued high relative abundances of $F$. curta and F. cylindrus, as well as the benthic diatom group (Fig. 6) and by very low abundances of the open ocean diatoms $F$. kerguelensis and T. lentiginosa (Fig. 6). Annual and spring insolation at $65^{\circ} \mathrm{S}$ reached a minimum $2000 \mathrm{yr}$ ago, while summer insolation attained its Holocene maximum. We suggest that, despite maximum summer insolation, summer duration was probably its shortest since the early Holocene, and that colder and longer winter and spring seasons would have likely promoted longer sea ice seasons. Such a scenario is supported by previous work, both locally in Marguerite Bay (Allen et al., 2010) and remotely in East Antarctica (Pike et al., 2009).

Although heavy spring sea ice conditions might have prevailed during the last $2100 \mathrm{yr}$, increasing $\mathrm{TEX}_{86}^{\mathrm{L}}$-derived temperatures, triene concentration and T. antarctica warm variety abundances paradoxically imply relatively warmer conditions during the ice-free months, and thus a rather rapid transition from a cold spring to a warm summer. Indeed, the T. antarctica data exhibit large swings with both warm and cold varieties evolving in concert (Fig. 5), probably indicating contrasting seasonal conditions. Our inferred warm summer conditions are in agreement with the increased melting of glacial ice between 3600 and $300 \mathrm{yr}$ BP (Pike et al., 2013). Furthermore, CRS relative abundance and total diatom abundance declined during this period (Fig. 6), an unexpected trend considering the extent of upper water column stratification anticipated from the combined melting of extensive sea ice cover and glacial ice (Pike et al., 2013). We suggest that stronger wind action during the late Holocene decreased surface water column stratification, which in turn reduced 
diatom abundance during this period, as already evidenced in Bransfield Strait (Heroy et al., 2008). A regime shift of this nature would have likely hindered a long, stable period of stratification and curtailed the associated growing season, as evidenced by the decreasing trends in CRS and total diatom abundance.

It is unlikely that variations in seasonal insolation alone were responsible for the climatic changes observed over the WAP during the mid- to late Holocene. For example, despite low and relatively stable annual and spring insolation since $2000 \mathrm{yr}$ BP, our records continued to show large amplitude changes throughout this period. Furthermore, orbitally simulated atmospheric temperatures indicate summer cooling and relatively stable winter and spring conditions (Renssen et al., 2005), which is inconsistent with our results and other geological records from the Antarctic Peninsula (e.g., Shevenell et al., 2011). An additional explanation is therefore required.

\subsubsection{The influence of ENSO in the WAP}

An intriguing aspect of the D/T ratio from core JPC-10 is the increased range of variability from $\sim 4500$ to $4000 \mathrm{yr}$ BP and again from $\sim 1200 \mathrm{yr} \mathrm{BP}$ to the present. The applicability of this proxy as an indicator of sea ice suggests greater variability of sea ice extent during those time intervals. The question is not only what caused the changes in the average $\mathrm{D} / \mathrm{T}$ ratio, but also what is the cause of higher frequency variability?

Similar high climate variability has been found at low latitudes since $\sim 5000 \mathrm{yr} \mathrm{BP}$ and has been related to the intensification of centennial scale ENSO activity (Chazen et al., 2009; Conroy et al., 2008; Moy et al., 2002). Moreover, recent work demonstrates the impact of ENSO on Antarctic climate (Kwok and Comiso, 2002; Turner et al., 2004; Yuan and Martinson, 2000; Shevenell et al., 2011). Strength and frequency of ENSO vary in line with changes in east-west temperature and pressure gradients along the equatorial $\mathrm{Pa}$ cific. Regarding the Antarctic Peninsula, El Niño events result in high pressures over the Amundsen Sea, advect cold air from the south and promote a cooling of sea surface temperatures and heavier sea ice conditions. Conversely, La Niña events promote a deeper Amundsen Sea low and generate a flow of warm and northerly air across the WAP (Yuan, 2004; Stammerjohn et al., 2008a; Russell and McGregor, 2010). Temperatures and sea ice in the Antarctic Peninsula are more sensitive to La Niña than El Niño events and respond with greater amplitude to the former (Yuan and Martinson, 2000). These two climatic states also induce a shift in the Westerlies, with the circumpolar wind belt transposed further south during La Niña events, which would in turn cause an increase in the upwelling of warm UCDW. Thereafter, the El Niño and La Niña signals would propagate into the warming WAP surface waters (Martinson et al., 2008; Willmott et al., 2010; Steig, 2012).

Records from the equatorial Pacific document less frequent and intense ENSO events during the early Holocene
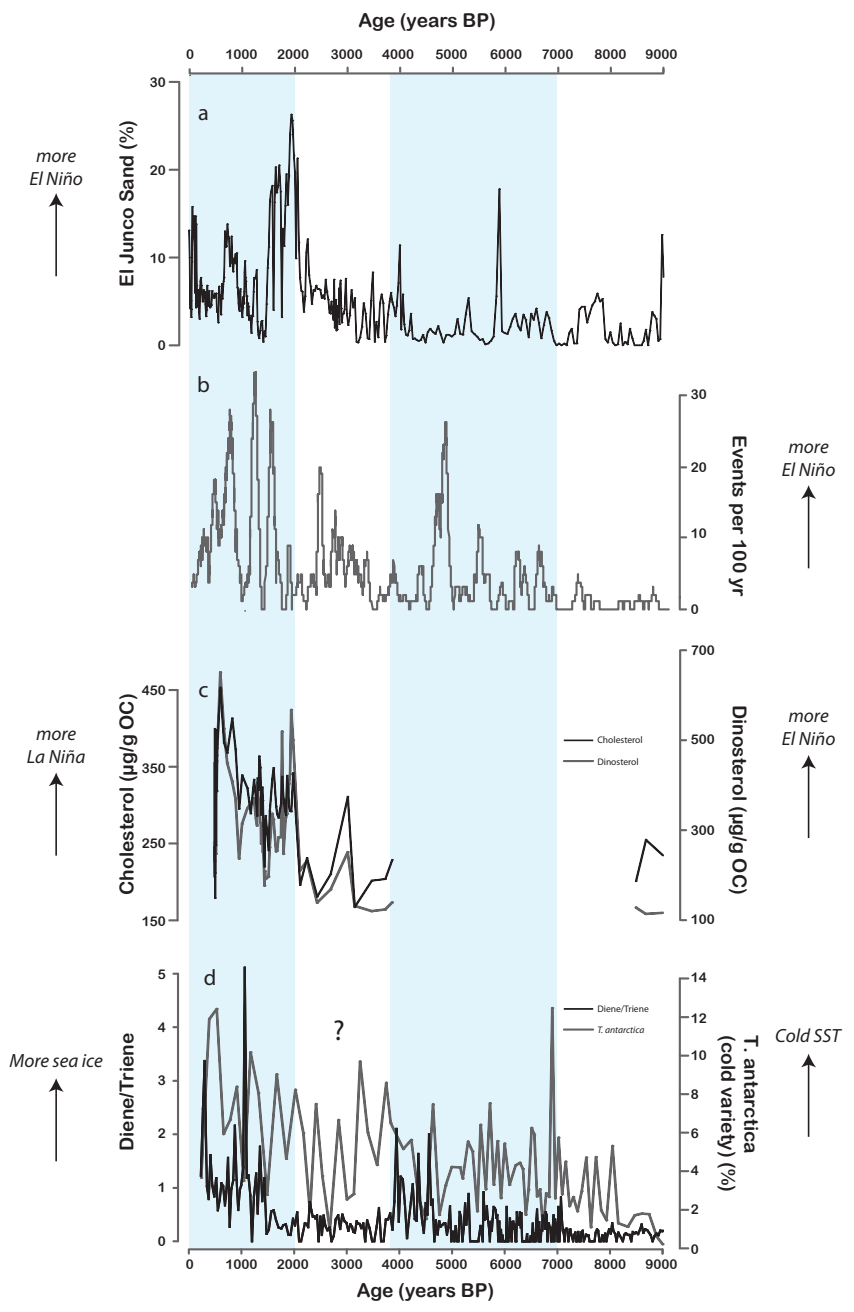

Fig. 8. (a) El Junco sand (\%) from Galapagos Islands sedimentary cores (Conroy et al., 2008), (b) ENSO frequency (events per $100 \mathrm{yr}$ ) from Ecuadorian lake records, (Moy et al., 2002), (c) cholesterol and dinosterol concentrations ( $\mu \mathrm{g} / \mathrm{g}$ OC) from Peruvian margin sediments (Makou et al., 2011) and (d) the JPC-10 D/T ratio records. Four major phases are demarcated in this figure, representing four different periods in the $\mathrm{D} / \mathrm{T}$ variations. The most important $\mathrm{D} / \mathrm{T}$ ratio increase corresponds well to significant ENSO events. Note the absence of ENSO and D/T correlations between $\sim 3800$ and $2100 \mathrm{yr} \mathrm{BP}$.

(Conroy et al., 2008; Moy et al., 2002; Makou et al., 2011) when uniformly low D/T ratios in core JPC10 indicated reduced sea ice cover (Fig. 8). From $\sim 7000$ to $3800 \mathrm{yr}$ BP, sea ice extent and variability demonstrate increasing trends in concert with the onset of increasing ENSO variability (Conroy et al., 2008; Moy et al., 2002). Between $\sim 3800$ and $2100 \mathrm{yr}$ BP, lower sea ice extent and reduced variability are recorded in phase, while ENSO activity was similar to the previous period. Finally, over the last $2100 \mathrm{yr}$ BP, increasing ENSO frequency and intensity and the emergence of stronger El Niño and La Niña events (Makou et al., 2011) appear 
coincident with the greatest variability in the $\mathrm{D} / \mathrm{T}$ ratio and temperature records. We suggest, in line with Shevenell et al. (2011) and Pike et al. (2013), that ENSO variability may have been one of the main drivers of the sea ice seasonal cycle at centennial to millennial timescales in the WAP, with an increasing influence over the last $2100 \mathrm{yr}$. ENSO impact is also evidenced by more frequent ice melt events at Siple Dome during the late Holocene as a result of increased storm activity and inland movement of maritime warm and moist air (Das and Alley, 2008). However, considering the lack of correlation between our records and ENSO variability between $\sim 3800$ and $2100 \mathrm{yr} \mathrm{BP}$, we further propose that other factors, also linked to the Antarctic Dipole (the Southern Annular Mode) and other low-latitude climate oscillations (e.g., Indian or Atlantic Ocean Dipole), may also play a role in controlling sea ice in the Antarctic Peninsula, which may explain this transition period, marking the onset of a strong seasonality shift. This shift is illustrated by both an increase in diene and triene concentrations, the intensification of glacial ice melt (Pike et al., 2013) and may well have contributed to surface temperature cooling. Clearly, the role of ENSO and other climatic forcing of Southern Ocean climate need further investigation.

Our results indicate that sea ice generally persisted longer during phases of stronger El Niño/La Niña events while upper ocean temperatures increased. During strong ENSO events, it is likely that a southernmost position of the Westerlies would be accompanied by a reinforcement of the upwelling of warm waters, which would in turn affect the WAP surface waters and preclude thick and long seasonal sea ice cover (Martinson et al., 2008; Willmott et al., 2010). However, the HBI record is not consistent with such a scenario. Instead, increasing presence of sea ice coincided with higherderived temperatures during the past $2000 \mathrm{yr}$. This paradox is also demonstrated by high relative abundances of both the warm and cold varieties of $T$. antarctica (Fig. 6). These data can be reconciled if we reasonably suppose that the increasing ENSO frequency associated with more El Niño/La Niña events (Makou et al., 2011) and the seasonal position of the Westerlies might have led to an increase in seasonal amplitude between the warm summer and cold winter seasons.

A recent modeling study showed that orbital forcing induces a greater seasonality in the position of the Westerlies over the course of the Holocene (Varma et al., 2012). They showed an equatorward displacement of the southern westerlies wind belt and surface temperatures cooling during the spring season, which is supported by our inferred longer spring presence of sea ice. In contrast, the model estimates a southward migration of the Westerlies and greatest surface temperature warming during summer and autumn, which is in agreement with our reconstructed elevated temperatures during the late Holocene. As such, the combination of precessional insolation and the centennial expression of low latitude climate modes might have led to the alternation of extremely warm summer and cold winter/spring temperatures recorded in core JPC-10 and reported off East Antarctica (Denis et al., 2010; Kim et al., 2012). Such particular conditions may also have favored the strong melting of glacial ice (Pike et al., 2013) during the summer. Our results indicate that the evolution of atmospheric conditions during the Holocene affected oceanic conditions, which retroactively altered atmospheric conditions; a strong ocean-atmosphere coupling that would mostly explain Holocene climate variability along the WAP.

\section{Summary and conclusions}

In this study, we examined the WAP climate variability over the last $9000 \mathrm{yr}$ BP using a suite of proxies, including diatom assemblage data and biomarkers, to reconstruct the variations in sea ice, temperature and diatom productivity from a core located in the Palmer Deep Basin. Overall, the data document a cooling trend and gradually increasing sea ice extent throughout the Holocene, potentially in response to decreasing annual and spring insolation. This lends support to recent suggestions that decreasing regional annual and seasonal mean insolation were the main drivers of temperature and sea ice changes occurring in the Southern Hemisphere over the last climatic cycle (Huybers and Denton, 2008).

Early Holocene warmth was characterized by a longer sea ice-free season, with warm upper ocean temperatures probably linked to high winter and spring insolation, warm air temperatures and the upwelling of warm UCDW. Coeval with declining insolation, the mid-Holocene was in contrast characterized by a cooling trend, longer seasonal sea ice duration and extensive marginal ice zone conditions, which in turn resulted in maximum regional productivity. During the late Holocene, particularly over the last $2100 \mathrm{yr}$ BP, the WAP experienced a major climatic step, and was characterized by a longer sea ice season, but warmer sea surface temperatures in summer. We suggest that increasing ENSO frequency and decreasing insolation might have, together, amplified the seasonal contrast between a cold winter and a warm summer through the Holocene.

We note that, for the period between 3800 and $2100 \mathrm{yr} \mathrm{BP}$, the correlation between HBIs and $\mathrm{TEX}_{86}^{\mathrm{L}}$ records and ENSO variability is by no means strong. We propose the operation of additional influencing factors related to the West and East Antarctic dipoles (SAM), northern high latitudes (e.g., AMOC) and/or other tropical/subtropical climate influences (e.g., Indian Ocean Dipole) expressed through oceanic and atmospheric teleconnections during this period. Thus, further high-resolution investigations around the Antarctica Peninsula, particularly in the eastern sector, are required for a better understanding of the processes controlling WAP climate during this period of time. 
Acknowledgements. We greatly thank Marie-Hélène Taphanel for technical assistance. We acknowledge funding from the French ANR CLIMICE, ERC ICEPROXY 203441, ESF PolarClimate HOLOCLIP 625 and FP7 Past4Future as well as the Netherlands Organisation of Scientific Research (NWO) through a VICI grant to Stefan Schouten. The HOLOCLIP Project, a joint research project of ESF PolarCLIMATE programme, is funded by national contributions from Italy, France, Germany, Spain, Netherlands, Belgium and the United Kingdom. The research leading to these results has also received support from the European Union's Seventh Framework programme (FP7/2007-2013) under grant agreement no. 243908, "Past4Future, Climate change - Learning from the past climate". This is HOLOCLIP contribution no. 18 and Past4Future contribution no. 51.

Edited by: N. Abram

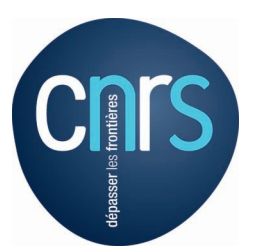

The publication of this article is financed by CNRS-INSU.

\section{References}

Abram, N., Mulvaney, R., Wolff, E.W., Triest, J., Kipfsthul, S., Trusel, L.D., Vimeux, F., Fleet, L., and Arrowsmith, C.: Acceleration of snow melt in an Antarctic Peninsula ice core during the twentieth century, Nat. Geosci., 6, 404-411, doi:10.1038/NGEO1787, 2013.

Allen, C. S., Pike, J., Pudsey, C. J., and Leventer, A.: Submillennial variations in ocean conditions during deglaciation based on diatom assemblages from the southwest Atlantic, Paleoceanography, 20, PA2012, doi:10.1029/2004PA001055, 2005.

Allen, C. S., Oakes-Fretwell, L., Anderson, J. B., and Hodgson, D. A.: A record of Holocene glacial and oceanographic variability in Neny Fjord, Antarctic Peninsula, Holocene, 20, 551-564, 2010.

Alonso-Sáez, L., Waller, A. S., Mende, D. R., Bakker, K., Farnelid, H., Yager, P. L., Lovejoy, C., Tremblay, J.-É. Potvin, M., Heinrich, F., Estrada, Riemann, M., L., Bork, P., Pedrós-Alió, C., and Bertilsson, S.: Role for urea in nitrification by polar marine Archaea, Proc. Natl. Acad. Sci. USA, 109, 17989-17994, doi:10.1073/pnas.1201914109, 2012.

Anderson, R. F., Ali, S., Bradtmiller, L. I., Nielsen, S. H. H., Fleisher, M. Q., Anderson, B. E., and Burckle, L. H.: Winddriven upwelling in the Southern Ocean and the deglacial rise in atmospheric $\mathrm{CO}_{2}$, Science, 323, 1443-1448, 2009.

Annett, A. L., Carson, D. S., Crosta, X., Clarke, A., and Ganeshram, R. S.: Seasonal progression of diatom assemblages in surface waters of Ryder Bay, Antarctica, Polar Biol., 33, 13-29, 2010.

Arrigo, K. R., van Dijken, G. L., Ainley, D. G., Fahnestock, M. A., and Markus, T.: Ecological impact of a large Antarctic iceberg, Geophys. Res. Lett., 29, 8-1-8-4, doi:10.1029/2001GL014160, 2002.

Barbara, L., Crosta, X., Massé, G., and Ther, O.: Deglacial envrionments in eastern Prydz Bay, East Antarctica, Quaternary Sci. Rev., 29, 2731-2740, 2010.
Barber, D. C., Dyke, A., Hillaire-Marcel, C., Jennings, A. E., Andrews, J. T., Kerwin, M. W., Bilodeau, G., McNeely, R., Southon, J., Morehead, M. D., and Gagnon, J.-M.: Forcing of the cold event of 8,200 years ago by catastrophic drainage of Laurentide lakes, Nature, 400, 344-348, 1999.

Belt, S. T., Allard, W. G., Massé, G., Robert, J. M., and Rowland, S. J.: Highly branched isoprenoids (HBIs): identification of the most common and abundant sedimentary isomers, Geochim. Cosmoschim. Acta, 64, 3839-3851, 2000.

Belt, S. T., Massé, G., Rowland, S. J., Poulin, M., Michel, C., and LeBlanc, B.: A novel chemical fossil of palaeo sea ice: IP25, Org. Geochem., 38, 16-27, 2007.

Bentley, M. J., Hodgson, D. A., Smith, J. A., Ó Cofaigh, C., Domack, E. W., Larter, R. D., Roberts, S. J., Brachfeld, S., Leventer, A., Hjort, C., Hillenbrand, C.-D., and Evans, J.: Mechanisms of Holocene palaeoenvironmental change in the Antarctic Peninsula region, Holocene, 19, 51-69, 2009.

Berger, A. and Loutre, M. F.: Insolation values for the climate of the last 10 million years, Quarternary Sci. Rev., 10, 297-317, 1991.

Buffen, A., Leventer, A., Rubin, A., and Hutchins, T.: Diatom assemblages in surface sediments of the northwestern Weddell Sea, Antarctic Peninsula, Marine Micropal., 62, 7-30, 2007.

Chazen, C. R., Altabet, M. A., and Herbert, T.: Abrupt midHolocene onset of centennial-scale climate variability on the Peru-Chile Margin, Geophys. Res. Let., 36, L18704, doi:10.1029/2009GL039749, 2009.

Collins, L. G., Pike, J., Allen, C. S., and Hodgson, D. A. High resolution reconstruction of Southwest Atlantic sea-ice and its role in the carbon cycle during Marine Isotope Stages 3 and 2, Paleoceanography, 27, PA3217, doi:10.1029/2011PA002264, 2012.

Collins, L. G., Allen, C. S., Pike, J., Hodgson, D. A., Weckstrom, K., and Masse, G.: Evaluating highly branched isoprenoid (HBI) biomarkers as a novel Antarctic sea-ice proxy in deep ocean glacial age sediments, Quaternary Sci. Rev., doi:10.1016/j.quascirev.2013.02.004, in press, 2013.

Conroy, J. L., Overpeck, J. T., Cole, J. E., Shanahan, T. M., and Steinitz-Kannan, M.: Holocene changes in eastern tropical Pacific climate inferred from a Galápagos lake sediment record, Quaternary Sci. Rev., 27, 1166-1180, 2008.

Cowie, R. O. M., Maas, E. W., and Ryan, K. G.: Archaeal diversity revealed in Antarctic sea ice, Antarct. Sci., 23, 531-536, 2011.

Crosta, X. and Koç, N.: Diatoms: From Micropaleontology to Isotope Geochemistry, in "Developments in Marine Geology", 327369, Elsevier, 2007.

Crosta, X., Pichon, J.-J., and Labracherie, M.: Distribution of Chaetoceros resting spore in modern peri-Antarctic sediments, Mar. Micropal., 29, 283-299, 1997.

Crosta, X., Pichon, J. J., and Burckle, L. H.: Application of modern analog technique to marine Antarctic diatoms: Reconstruction of maximum sea-ice extent at the Last Glacial Maximum, Paleoceanography, 13, 284-297, 1998.

Crosta, X., Sturm, A., Armand, L., and Pichon, J. J.: Late Quaternary sea ice history in the Indian sector of the Southern Ocean as recorded by diatom assemblages, Mar. Micropal., 50, 209-223, 2004.

Crosta, X., Debret, M., Denis, D., Courty, M. A., and Ther, O.: Holocene long- and short-term climate changes off Adelie Land, East Antarctica, Geochem. Geophys. Geosyst., 8, 1-15, 2007. 
Crosta, X., Denis, D., and Ther, O.: Sea ice seasonality during the Holocene, Adélie Land, East Antarctica, Mar. Micropal., 66, 222-232, 2008.

Das, S. and Alley, R. B.: Rise in frequency of surface melting at Siple Dome through the Holocene: Evidence for increasing marine influence on the climate of West Antarctica, J. Geophys. Res.-Atmos., 113, D02112, doi:10.1029/2007JD008790, 2008.

Denis, D., Crosta, X., Zaragosi, S., Romero, O., Martin, B., and Mas, V.: Seasonal and subseasonal climate changes recorded in laminated diatom ooze sediments, Adelie Land, East Antarctica, Holocene, 16, 1137-1147, 2006.

Denis, D., Crosta, X., Barbara, L., Massé, G., Renssen, H., Ther, O., and Giraudeau, J.: Sea ice and wind variability during the Holocene in East Antarctica: insight on middle-high latitude coupling, Quaternary Sci. Rev., 29, 3709-3719, 2010.

Dierssen, H. M., Smith, R. C., and Vernet, M.: Glacial meltwater dynamics in coastal waters west of the Antarctic peninsula, Proc. Natl. Acad. Sci. USA, 99, 1790-1795, 2002.

Doake, C. S. M. and Vaughan, D. G.: Rapid disintegration of the wordie ice shelf in response to atmospheric warming, Nature, 350, 328-330, 1991.

Domack, E., Leventer, A., Dunbar, R., Taylor, F., Brachfeld, S., and Sjunneskog, C.: Chronology of the Palmer Deep site, Antarctic Peninsula: a Holocene palaeoenvironmental reference for the circum-Antarctic, Holocene, 11, 1-9, 2001.

Domack, E., Leventer, A., Burnett, A., Bindschadler, R., Convey, P. and Kirby, M., 2003: Antarctic Peninsula Climate Variability: Historical and Paleoenvironmental Perspectives. Antarct. Res. Ser. AGU, Washington, DC, 260 pp., 2003.

Ellison, C. R. W., Chapman, M. R., and Hall, I. R.: Surface and deep ocean interactions during the cold climate event 8200 years ago, Science, 312, 1929-1932, 2006.

Fryxell, G. A.: Marine phytoplankton at the Weddell Sea ice edge: seasonal changes at the specific level, Polar Biol., 10, 1-18, 1989.

Fryxell, G. A. and Prasad, A. K. S. K.: Eucampia antarctica var. recta (Mangin) stat. nov. (Biddulphiaceae, Bacillariophyceae): life stages at the Weddell Sea ice edge, Phycologia, 29, 27-38, 1990.

Gersonde, R. and Zielinski, U.: The reconstruction of Late Quaternary Antarctic sea-ice distribution - the use of diatoms as a proxy for sea ice, Palaeogeo. Palaeoclim. Palaeoecol., 162, 263-286, 2000.

Gersonde, R., Crosta, X., Abelmann, A., and Armand, L.: Seasurface temperature and sea ice distribution of the Southern Ocean at the EPILOG Last Glacial Maximum - a circumAntarctic view based on siliceous microfossil records, Quaternary Sci. Rev., 24, 869-896, 2005.

Grzymski, J. J., Riesenfeld, C. S., Williams, T. J., Dussaq, A. M., Ducklow, H., Erickson, M., Cavicchioli, R., and Murray, A. E.: A metanogenomic assessment of winter and summer bacterioplankton from Antarctica Peninsula costal surface water, ISME J., 6, 1901-1915, 2012.

Heroy, D. C., Sjunneskog, C., and Anderson, J. B.: Holocene climate change in the Bransfield basin, Antarctic Peninsula: evidence from sediment and diatom analysis, Antarctic Sci., 20, 69-87, 2008.

Hopmans, E. C., Schouten, S., Pancost, R. D., Meer, J. v. d., and Sinninghe Damsté J. S.: Analysis of intact tetraether lipids in archaeal cell material and sediments using high performance liq- uid chromatography/atmospheric pressure ionization mass spectrometry, Rapid Com. Mass Spectrom., 14, 585-589, 2000.

Hopmans, E. C., Weijers, J. W. H., Schefuß, E., Herfort, L., Sinninghe Damsté, J. S., and Schouten, S.: A novel proxy for terrestrial organic matter in sediments based on branched and isoprenoid tetraether lipids, Earth Planet. Sci. Lett., 224, 107-116, 2004.

Huybers, P. and Denton, G.: Antarctic temperature at orbital timescales controlled by local summer duration, Nat. Geosci., 1, 787-792, 2008.

Iizuka, Y., Hondoh, T., and Fujii, Y.: Antarctic sea ice extent during the Holocene reconstructed from inland ice core evidence, J. Geophys. Res., 113, D15114, doi:10.1029/2007JD009326, 2008.

Ishman, S. E. and Sperling, M. R.: Benthic foraminiferal record of Holocene deep-water evolution in the Palmer Deep, western Antarctic Peninsula, Geology, 30, 435-438, 2002.

Jensen, S., Renberg, L., and Reutergårdh.: Residue analysis of sediment and sewage sludge for organochlorines in the presence of elemental sulphur, Anal. Chem., 49, 316-318, 1977.

Johns, L., Wraige, E. J., Belt, S. T., Lewis, C. A., Massé, G., Robert, J.-M., and Rowland, S. J.: Identification of C25 Highly Branched Isoprenoid (HBI) Dienes in Antarctic sediments, sea-ice diatoms and laboratory cultures of diatoms, Org. Geochem., 30, 14711475, 1999.

Joughin, I. and Alley, R. B.: Stability of the West Antarctic ice sheet in a warming world, Nat. Geosci., 4, 506-513, 2011.

Kaczmarska, I., Barbrick, N. E., Ehrman, J. M., and Cant, G. P.: Eucampia Index as an indicator of the Late Pleistocene oscillations of the winter sea-ice extent at the ODP Leg 119 Site 745B at the Kerguelen Plateau, Hydrobiologia, 269/270, 103-112, 1993.

Kalanetra, K. M., Bano, N., and Hollibaugh, J. T.: Ammoniaoxidizing Archaea in the Arctic Ocean and Antarctic coastal waters, Environ. Microbiol., 11, 2434-2445, 2009.

Kim, J.-H., Schouten, S., Hopmans, E.., Donner, B., and Sinninghe Damsté, J. S.: Global sediment core-top calibration of the TEX 86 paleothermometer in the ocean, Geochim. Cosmochim. Acta, 72, 1154-1173, 2008.

Kim, J.-H., Meer, J. v. d., Schouten, S., Helmke, P., Wilmott, V., Sangiorgi, F., Koç, N., Hopmans, E. C., and SinningheDamsté, J. S.: New indices and calibrations derived from the distribution of creanarchaealisoprenoidtetraether lipids: Implications for past sea surface temperature reconstructions, Geochim. Cosmochim. Acta, 74, 4639-4654, 2010.

Kim, J.-H., Crosta, X., Willmott, V., Renssen, H., Massé, G., Bonnin, J., Helmke, P., Schouten, S., and Sinninghe Damsté, J. S.: Increase in Late Holocene subsurface temperature variability in East Antarctica, Geophys. Res. Lett., 39, L06705, doi:10.1029/2012GL051157, 2012.

King, J.: Recent climate variability in the vicinity of the Antarctic Peninsula, Int. J. Climatol., 14, 357-369, 1994.

Klinck, J. M., Hofmann, E. E., Beardsley, R. C., Salihoglu, B., and Howard, S.: Watermass properties and circulation on the west Antarctic Peninsula Continental Shelf in Austral Fall and Winter 2001, Deep-Sea Res. Part II, 51, 1925-1946, 2004.

Krebs, W. N.: Ecology of neritic marine diatoms, Arthur Harbor, Antarctica, Micropaleontology, 29, 267-297, 1983.

Kwok, R. and Comiso, J. C.: Southern Ocean climate and sea ice anomalies associated with the Southern Oscillation, Am. Meteorol. Soc., 15, 487-501, 2002. 
Lamy, F., Kilian, R., Arz, H. W., François, J.-P., Kaiser, J., Prange, M., and Steinke, T.: Holocene changes in the position and intensity of the southern westerly wind belt, Nat. Geosci., 3, 695-699, 2010.

Leventer, A.: The fate of Antarctic "sea-ice diatoms" and their use as paleoenvironmental indicators, in: Antarctic sea ice biological processes, interactions and variability, AGU Antarctic Res. Series, edited by: Lizotte, M. and Arrigo, K., 121-137, 1626-1644, 1998.

Leventer, A., Domack, E. W., Ishman, S. E., Brachfeld, S., McClennen, C. E., and Manley, P.: Productivity cycles of 200-300 years in the Antarctic Peninsula region: Understanding linkages among the sun, atmosphere, oceans, sea ice, and biota, Geolog. Soc. Am. Bull., 108, 1626-1644, 1996.

Leventer, A., Domack, E., Barkoukis, A., McAndrews, B., and Murray, J.: Laminations from the Palmer Deep: A diatom-based interpretation, Paleoceanography, 17, doi:10.1029/2001PA000624, 2002.

Levitus, S. and Boyer, T.P.: World Ocean Atlas 1994, Volume 4: Temperature, number 4, 1994.

Levitus, S., Antonov, J. I., Boyer, T. P., and Stephens, C.: Warming of the world ocean, Science, 287, 2225-2229, 2000.

Makou, M. C., Eglinton, T. I., Oppo, D. W., and Hughen, K. A.: Postglacial changes in El Niño and La Niña behavior, Geology, 38, 43-46, 2011.

Marinov, I., Gnanadesikan, A., Toggweiler, J. R., and Sarmiento, J. L.: The Southern Ocean biogeochemical divide, Nature, 441, 964-967, 2006.

Martinson, D. G., Stammerjohn, S. E., Iannuzzi, R. A., Smith, R. C., and Vernet, M.: Western Antarctic Peninsula physical oceanography and spatio-temporal variability, Deep Sea Res. Part II, 55, 1964-1987, 2008.

Massé, G., Rowland, S. J., Sicre, M.-A., Jacob, J., Jansen, E., and Belt, S. T.: Abrupt climate changes for Iceland during the last millennium: Evidence from high resolution sea ice reconstructions, Earth Planet. Sci. Lett., 269, 564-568, 2008.

Massé, G., Belt, S., Crosta, X., Schmidt, S., Snape, I., Thomas, D. N., and Rowland, S. J.: Highly branched isoprenoids as proxies for variable sea ice conditions in the Southern Ocean, Antarct. Sci., 23, 487-498, 2011.

Moffat, C., Breadsley, R. C., Owens, B., and van Lipzig, N.: A first description of the Antarctic Peninsula Coastal Current, Deep Sea Res. Part II, 55, 277-293, 2008.

Montade, V., Combourieu Nebout, N., Chapron, E., Mulsow, S., Abarzúa, A. M., Debret, M., Foucher, A., Desmet, M., Winiarski, T., and Kissel, C.: Regional vegetation and climate changes during the last $13 \mathrm{kyr}$ from a marine pollen record in Seno Reloncaví, southern Chile, Rev. Palaeobotany and Palynology, 181, 11-21, 2012.

Moreno, P. I., François, J. P., Moy, C. M., and Villa-Martinez, R.: Covariability of the Southern Westerlies and atmospheric $\mathrm{CO}_{2}$ during the Holocene, Geology, 38, 727-730, 2010.

Morrill, C. and Jacobsen, R. M.: How widespread were climate anomalies 8200 years ago?, Geophys. Res. Lett., 32, L19701, doi:10.1029/2005GL023536, 2005.

Moy, C. M., Seltzer, G. O., Rodbell, D. T., and Anderson, D. M.: Variability of El Niño/Southern Oscillation activity at millennial timescales during the Holocene epoch, Nature, 420, 162-165, 2002.
Mulvaney, R., Abram, N. J., Hindmarsh, C. A., Arrowsmith, C., Fleet, L., Triest, J., Sime, L. C., Alemany, O., and Foord, S.: Recent Antarctic Peninsula warming relative to Holocene climate and ice-shelf history, Nature, 489, 141-145, 2012.

Murray, A. E., Preston, C. M., Massana, R., Taylor, L. T., Blakis, A., Wu, K., and DeLong, E. F.: Seasonal and spatial variability of bacterial and archaeal assemblages in the coastal waters near Anvers Island, Antarctica, Appl. Environ. Microbiol., 64, 25852595, 1998.

Nielsen, S. H. H., Koç, N., and Crosta, X.: Holocene climate in the Atlantic sector of the Southern Ocean: controlled by insolation or oceanic circulation?, Geology, 32, 317-320, 2004.

Orsi, A. H., Smethie Jr., W. M., and Bullister, J. L.: On the total input of Antarctic waters to the deep ocean: A preliminary estimate from chlorofluorocarbon measurements, J. Geophys. Res., 107, 3122, doi:10.1029/2001JC000976, 2002.

Pike, J., Allen, C. S., Leventer, A., Stickley, C., and Pudsey, C. J.: Comparison of contemporary and fossil diatom assemblages from the western Antarctic Peninsula shelf, Mar. Micropal., 67, 274-287, 2008.

Pike, J., Crosta, X., Maddison, E. J., Stickley, C. E., Denis, D., Barbara, L., Renssen, H., and Leventer, A.: Observations on the relationship between the Antarctic coastal diatoms Thalassiosira antarctica Comber and Porosira glacialis (Grunow) Jørgensen and sea ice concentrations during the Late Quaternary, Mar. Micropal., 73, 14-25, 2009.

Pike, J., Swann, G. E. A., Leng, M. J., and Snelling, A. M.: Glacial discharge along the west Antarctic Peninsula during the Holocene, Nat. Geosci., 6, 199-202, 2013.

Renssen, H., Goosse, H., Fichefet, T., Masson-Delmotte, V., and Koc, N.: Holocene climate evolution in the high-latitude Southern Hemisphere simulated by a coupled atmosphere-sea iceocean-vegetation model, Holocene, 15, 951-964, 2005.

Rignot, E.: Changes in ice dynamics and mass balance of the Antarctic ice sheet, Philosophical transactions of the royal society, 364, 1637-1655, 2006.

Rintoul, S. R., Hughes, C. W., and Olbers, D.: The Antarctic Circumpolar Current System, in: Ocean Circulation and Climate. Observing and Modelling the Global Ocean, edited by: Siedler, G., Church, J., and Gould, J., 271-302, Academic Press, 2001.

Riis, V. and Babel, W.: Removal of sulfur interfering in the analysis of organochlorines by GC-ED, Analyst, 124, 1771-1773, 1999.

Robson, J. N., and Rowland, S. J.: Biodegradation of highly branched isoprenoid hydrocarbons: A possible explanation of sedimentary abundance, Org. Geochem., 13, 691-695, 1988.

Rohling, E. J. and Pälike, H.: Centennial-scale climate cooling with a sudden cold event around 8,200 years ago, Nature, 434, 975979, 2005.

Rott, H., Skvarca, P., and Agler, T.: Rapid collapse of Northern Larsen Ice Shelf, Antarct. Sci., 271, 788-792, 1996.

Russell, A. and McGregor, G.: Southern Hemisphere atmospheric circulation: impacts on Antarctic climate and reconstructions from Antarctic ice core data, Clim. Change, 99, 155-192, 2010.

Sarmiento, J. L., Gruber, N., Brzezinski, M. A., and Dunne, J. P.: High-latitude controls of thermocline nutrients and low latitude biological productivity, Nature, 427, 56-60, 2004.

Schouten, S., Hopmans, E. C., Schefuß, E., and Sinninghe Damsté, J. S.: Distributional variations in marine crenarchaeotal membrane lipids: A new organic proxy for reconstructing ancient sea 
water temperatures, Earth Planet. Sci. Lett., 204, 265-274, 2002.

Schouten, S., Huguet, C., Hopmans, E. C., Kienhuis, M., and Sinninghe Damsté J. S.: Analytical Methodology for TEX86 Paleothermometry by High-Performance Liquid Chromatography/Atmospheric Pressure Chemical Ionization-Mass Spectrometry, Anal. Chem., 79, 2940-2944, 2007.

Shevenell, A. E. and Kennett, J. P.: Antarctic Holocene climate change: a benthic foraminifer stable isotope record from Palmer Deep, Paleoceanography, 17, doi:10.1029/2000PA000596, 2002.

Shevenell, A. E., Domack, E. W., and Kernan, G. M.: Record of Holocene palaeoclimate change along the Antarctic Peninsula: evidence from glacial marine sediments, Lallemand Fjord, Papers and Proceedings of the Royal Society of Tasmania, 130, 55-64, 1996.

Shevenell, A. E., Ingalls, A. E., Domack, E. W., and Kelly, C.: Holocene Southern Ocean surface temperature variability west of the Antarctic Peninsula, Nature, 470, 250-254, 2011.

Sievers, H. A. and Nowlin Jr., W. D.: The stratification and water masses at Drake Passage, J. Geophys. Res., 89, 10489-10514, 1984.

Sinninghe Damsté, J. S., Rijpstra, W. I. C., Coolen, M. J. L., Schouten, S., and Volkman, J. K.: Rapid sulfurisation of highly branched isoprenoid (HBI) alkenes in sulfidic Holocene sediments from Ellis Fjord, Antarctica, Org. Geochem., 38, 128-139, 2007.

Sjunneskog, C. and Taylor, F.: Postglacial marine diato record of the Palmer Deep, Antarctic Peninsula (ODP Leg 178, Site 1098) 1. Total diatom abundance, Paleoceanography, 17, doi:10.1029/2000PA000563, 2002.

Smith, D. A., Hofmann, E. E., Klinck, J. M., and Lascara, C. M.: Hydrography and circulation of the west Antarctic Peninsula continental shelf, Deep-Sea Res. Part I, 46, 925-949, 1999.

Stammerjohn, S. E. and Smith, R. C.: Spatial and temporal variability of western Antarctic Peninsula sea ice coverage, in: Foundations for ecological research west of the Antarctic Peninsula, 81-104, AGU, 1996.

Stammerjohn, S. E., Martinson, D. G., Smith, R. C., Yuan, X., and Rind, D.: Trends in Antarctic annual sea ice retreat and advance and their relation to El Nino-Southern Oscillation and Southern Annular Mode variability, J. Geophys. Res., 108, C03S90, doi:10.1029/2002JC001543, 2008a.

Stammerjohn, S. E., Martinson, D. G., Smith, R. C., and Iannuzzi, R. A.: Sea ice in the western Antarctic Peninsula region: Spatiotemporal variability from ecological and climate change perspectives, Deep Sea Res. Part II, 55, 2041-2058, 2008b.

Steig, E. J.: Climate change: brief but warm Antarctic summer, Nature, 498, 39-41, 2012.

Steig, E. J., Schneider, D. P., Rutherfold, S. D., Mann, M. E., Comiso, J. C., and Shindell, D. T.: Warming of the Antarctic ice-sheet surface since the 1957 International Geophysical year, Nature, 457, 459-463, 2009.
Taylor, F. and Sjunneskog, C.: Postglacial marine diatom record of the Palmer Deep, Antarctic Peninsula (ODP Leg 178, Site 1098) 2; Diatom assemblages, Paleoceanography, 17, doi:10.1029/2000PA000564, 2002.

Taylor, F., Whitehead, J., and Domack, E.: Holocene paleoclimate change in the Antarctic Peninsula: evidence from the diatom, sedimentary and geochemical record, Mar. Micropal., 41, 25-43, 2001.

Toggweiler, J. R., Russell, J. L., and Carson, S. R.: Mid latitude westerlies, atmospheric $\mathrm{CO}_{2}$, and climate change during the ice ages, Paleoceanography, 21, PA2005, doi:10.1029/2005PA001154, 2006.

Turner, J.: The El Niño-Southern Oscillation and Antarctica, Int. J. Climatol., 24, 1-31, 2004.

Varma, V., Prange, M., Merkel, U., Kleinen, T., Lohmann, G., Pfeiffer, M., Renssen, H., Wagner, A., Wagner, S., and Schulz, M. Holocene evolution of the Southern Hemisphere westerly winds in transient simulations with global climate models, Clim. Past 8, 391-402, doi:10.5194/cp-8-391-2012, 2012.

Vaughan, D. G. and Doake, C. S. M.: Recent atmospheric warming and retreat of ice shelves on the Antarctic Peninsula, Nature, 379, 328-331, 1996.

Vaughan, D. G., Marshall, G. J., Conrolley, W. M., Parkinson, C., Mulvaney, R., Hodgson, D. A., King, J. C., Pudsey, C. J., and Turner, J.: Recent rapid regional climate warming on the Antarctic Peninsula, Clim. Change, 60, 243-274, 2003.

Volkman, J. K., Barrett, S. M., and Dunstan, G. A.: $\mathrm{C}_{25}$ and $\mathrm{C}_{30}$ highly branchedisoprenoid alkenes in laboratory cultures of two marine diatoms, Org. Geochem., 21, 407-413, 1994.

Weijers, J. W. H., Schouten, S., Spaargaren, O., and Sinninghe Damsté, J. S.: Occurrence and distribution of tetraether membrane lipids in soils: Implications for the use of the TEX86 proxy and the BIT index, Org. Geochem., 37, 1680-1693, 2006.

Whitehead, J. M., Wotherspoon, S., and Bohaty, S. M.: Minimal Antarctic sea ice during the Pliocene, Geology, 33, 137-140, 2005.

Willmott, V., Rampen, S. W., Domack, E., Canals, M., and Sinninghe Damsté, J. S., and Schouten, S.: Holocene changes in Proboscia diatomproductivity in shelf waters of the north-western Antarctic Peninsula, Antarct. Sci., 22, 3-10, 2010.

Yoon, H. I., Park, B. K., Kim, Y., and Kan, C. Y.: Glaciomarine sedimentation and its paleoclimatic implications on the Antarctic Peninsula shelf over the last 15000 years, Palaeogeo., Palaeoclim., Palaeoeco., 185, 235-254, 2002.

Yuan, X.: ENSO-related impacts on Antarctic sea ice: a synthesis of phenomenon and mechanisms, Antarct. Sci., 16, 415-425, 2004.

Yuan, X. and Martinson, D. G.: Antarctic sea ice extent variability and its global connectivity, J. Climate, 13, 1697-1717, 2000. 